\title{
Sosyal Ağların İşlevlerini Etkileşim, Kimlik ve Değerler Üzerinden Düşünmek
}

\author{
Thinking of the Functions of Social Networks in the Context of Interaction, Identity and Values
}

\author{
Mehmet CARLIK \\ Öğr. Grv., Tokat Gaziosmanpaşa Üniversitesi, \\ Artova MYO,mehmet.carlik@gop.edu.tr \\ https://orcid.org/0000-0002-9668-4595
}

\section{Aslı ÖZTÜRK TERZI}

$\ddot{O} \breve{g r}$. Grv., Tokat Gaziosmanpaşa Üniversitesi, Artova MYO, asli.ozturk@gop.edu.tr https://orcid.org/0000-0001-5618-6762
Makale Başvuru Tarihi: 18.07.2020

Makale Kabul Tarihi: 11.12.2020

Makale Türü: Araştırma Makalesi

\section{ÖZET}

Anahtar

Kelimeler:

Sosyal $A \breve{g}$,

İslevsellik,

Etkileşim,

Kimlik,

Değer,

Keywords:

Social Network,

Functionality,

Interaction,

Identity,

Value,
Sosyal ă̆lar, bireylerin kullanıcı olarak inșa ettikleri kimlikler eşliğinde bir etkileşim ve değer unsuru oluşturmak için önemli faaliyet alanlarıdır. Bu çalışmanın amacı, sosyal ağlar üzerinde kullanıcıların gerçekleştirdikleri faaliyetler ve bu faaliyetlerden doğan değer, kimlik ve etkileşim bileşenlerini ayrıntılı olarak tanımlamak; sosyal ağların yedi işlevi olan mevcudiyet, kimlik, paylaşım, şöhret, ilişsi, sohbet ve grup faaliyetleri içinde, kullanıcıların etkileşim, değer ve kimlik bileşenlerini yönetmelerine yönelik bir bakış açısı oluşturmaktır. Sosyal ağların sunduğu işlevleriyle değer, kimlik ve etkileşim kavramları üzerindeki rolünün teorik çerçevesi irdelenerek, bu alanda yapılacak pratiğe dayalı araştırmaların teorik zeminini hazırlaması bakımından önemlidir. Çalışmanın kapsamı, sosyal ağların yedi işlevi dahilinde, değer, kimlik ve etkileşim bileşenlerini değerlendirmektir. Ilk olarak, dijitalleşmenin varlı̆̆ içinde sosyal ağlar ele alınmıştır. Devamında sosyal ağların işlevselliği, sosyal ağlarda etkileşim, kimlik ve değer ilişsisi ele alınmıştır. Genel olarak değerlendirildiğinde, sosyal ağların işlevsel süreçleri, sosyal ă̆ların çoklu yapısına paralel olarak çeşitli etkileşim olanakları sağlamaktadır. Sosyal ă̆ etkileşimselliğiyle, kullanıcı tarafindan şekillenen kimlikler, sosyal ă̆larda değerler ilişkisi kurarak kullanıcıların içerik üretimine göre kendi değer ilişkilerini belirleyebilmektedir.

\section{ABSTRACT}

Social Networks are an important field of activity for creating an element of value and interaction accompanying the identity created by individuals as users. The aim of the present study is to elaborately define the activities of users on social networks and the value, identity and interaction components arising from these activities; to establish a point of view for users to manage interaction, value and identity components within the seven functions of social networks: presence, identity, sharing, fame, relationship, communication and group activities. It is significant for the preparation of the theoretical foundation for practical studies by examining the theoretical framework of the functions of value, identity and interaction offered by social networks. The scope of this study is to evaluate the components of value, identity and interaction within the context of the 7 social networks. First of all,, social networks have been discussed within the presence of digitalization. Then, the relationship of functionality and interaction, identity and value of social networks has been addressed. When generally evaluated, the functionality process of social networks provides various interaction opportunities parallel to the multiple structures of social networks. The identities shaped by the user can establish a relationship of values in social network interactivity and determine their own value relationships according to the content production of the users. 


\section{GIRISS}

Dijitalleşmeyle oluşan değişimler, birçok duruma yeni dinamik bağlantılar ve ilişkiler getirmektedir. Ağlarla kurulan ilişkiler, bireyler arası ilişkilerin inşası için önemli bir temsil oluşturur. Bu temsil, dijitalleşme ile çeşitli değişimlere uğramaktadır. Bir küresel ölçek olarak kitlesel etkilenme sahası yaratması bakımından dijitalleşme, geniş anlamda oluşan ağ bağlantılarının temel karakteristik yapısını yeniden belirlemektedir. Bu belirtilerin oluşturduğu dönüşümler içinde bireylerin, zaman ve mekân kavramı olmadan, etkileşimlerini sürdürebilmeleri kolay bir hale gelmektedir.

Bir dijital yapı, dijitalleşmenin getirileri içinde yer alan değişimler ile ilişkilendirilmektedir. Değişimlerin sağladığı etkiler ile bir dijitalleşme olgusu, birçok kavram ve kavramlar arası ilişkileri şekillendirmektedir. Bir kavramı bağlayan ve onu inşa eden temel etkenlerin belirleyiciliği, dijital dönüşümün içinde yeniden üretilebilmektedir. Özellikle dijitalleşmenin çizdiği yol içinde; geniş, hızlı, etkili bir dönüşümden bahsetmek mümkündür.

Dijitalleşmenin getirdiği dönüşümler içinde bireyler ağ ilişkisini inşa ederken, yeni bir ağ zinciri etrafında etkileşim gerçekleştirmektedir. Bu durumu açık ve şeffaf kılabilen teknolojik alt yapıyı internet sağlamaktadır. Kesintisiz bir bilgi akışı sunan internet, bireylerin kullanımı noktasında, bir topluluk bağlantısı oluşturma imkânı sunar. Bu toplulukların dinamiği sürekli olarak değişkenlik göstermesiyle beraber, kişilerin ya da internet kullanıcılarının kendi kişisel süreçlerini inşa etmesiyle bir toplumsal paylaşım ağı özelliğine sahip olur. $\mathrm{Bu}$ anlamda, bir teknolojik devinim olarak internet, yeni bir ăg zincirinin oluşmasını etkin duruma getirmektedir. $\mathrm{Bu}$ özelliğin sosyal paylaşım ağlarıyla kullanıcılar arası etkileşimi şekillendirdiği söylenebilmektedir.

Sosyal paylaşım ağları, bireylerin kendilerini takdim ettiği ya da kişisel kullanıcı pratikleriyle etkileşime girdikleri sanal topluluklar için ortam yaratır/oluşturur. Sosyal paylaşım ağlarındaki kişisel kullanıcı kimlikleri, kişinin yönlendirmesi koşuluyla çeşitlilik gösterebilmektedir. Bu süreçte kullanıcıların ağ içerisinde kim olduklarını tanımlayabilmeleri için kimlik oluşturma gerekliliği ortaya çıkmaktadır. Sosyal paylaşım ağlarında, bireyler, kullanıcı kimliği ile ağ içerisinde var olarak diğer kullanıcılarla etkileşime girebilmektedir. Söz konusu etkileşim, kullanıcı hareketliliği sağlar ve bu hareket etme durumu da paylaşım yapma/yapabilme imkânı sunar.

Sosyal ağların sağladığı paylaşım yapabilme olanağı içinde bireyler, hareket alanları çerçevesinde tercih ettikleri paylaşım olanaklarıyla kendilerini ifade edebilmektedir. Bu anlamda, kullanıcı olan kişi oluşturduğu profili eşliğinde, diğer kullanıcı kişilerle etkileşime geçer ve sosyal ağlar içinde varlık gösterir. Kullanıcıların varlıklarını gösterebilmeleri için içerik üretimi yapmaları gerekir. Bununla birlikte bir kullanıcının sosyal ağlarda bir birey olarak anlam ifade etmesi, içerik üretimini şekillendirmesi ile gerçekleşmektedir. Dolayısıyla sosyal ağ kullanıcısı olan bireyler, içerik üretimi ile bir alana sahip olmaktadır ve bu kullanım alanında sosyal ilişki kurabilmektedir.

Fiziksel yaşama benzer ya da fiziksel yaşamdan farklı olarak bir kimlik oluşturma serbestliğine sahip olan kullanıcılar, sosyal ağlar çerçevesinde bir kimlik inşa etme sürecine girmektedir. Bireyler, sosyal ağlarda kullanıcı olarak bir kimlik dinamiği yaratmaktadırlar. Bu durum sayesinde kullanıcı kimlikleri işlevsel bir süreklilik göstermektedir. Kullanıcı kimliklerinin işlevselliği, bir yönetim süreci gerektirebilmektedir.

Bireyler, gündelik yaşamla ilgili birçok etkeni sosyal ağ platformlarına taşıyabilmektedir. Haliyle bireyler, gündelik hayat içinde oluşturdukları birtakım değer ve değer bileşenlerini, bir bireyin oluşturduğu kullanıcı profili eşliğinde, sosyal ağ eksenli devam ettirebilmektedirler. Bu anlamda, sosyal paylaşım ağları bir bireyin sanal uzamdaki değer sistemlerini ilişkilendirdiği bir araç olabilmektedir.

Sosyal paylaşım ağlarının kullanıcılar için önemli işlevleri bulunmaktadır. Kimlik, sohbet, paylaşım, mevcudiyet, ilişki, şöhret, grup işlevleri ile kullanıcılar etkileşim içine girebilmektedir. Burada oluşan etkileşim faaliyetleri, kullanıcıların kimliklerini kendi isteği şeklinde inşa etmeleri için çeşitlilik sağlamaktadır. Bunun yanında, kullanıcı endeksli bir değer yaratma boyutu olarak, içerik üretimi oluşturulabilmektedirler.

Çalışmanın amacı, sosyal ağlar üzerinde kullanıcıların gerçekleştirdikleri eylemlerden doğan değer, kimlik ve etkileşim bileşenlerini ayrıntılı olarak tanımlamak, sosyal ağların yedi işlevi olan mevcudiyet, kimlik, paylaşım, şöhret, ilişki, sohbet ve grup faaliyetleri içinde, kullanıcıların etkileşim, değer ve kimlik bileşenlerini yönetmelerine yönelik bir bakış açısı oluşturmaktır. Çalışmanın kapsamı, sosyal ağların yedi işlevi çerçevesinden, değer, kimlik ve etkileşim bileşenlerini değerlendirmektir. 


\section{BİR DİJITTAL AĞ ONTOLOJISİ: SOSYAL AĞLAR}

Dijitalleşme, dijital değişimin getirdiği yenilikler içinde yer alan aşamaların gösterdiği büyümeye dayalı bir "sayısallaşma" olgusu olarak bilinmektedir (Verhoef vd., 2019:2). Teknik bir terim olarak dijitalleşme, bilgi sistemleri içinde analog sinyallerin veri olarak dijital sinyallere dönüşümünü belirtmektedir (Eller vd., 2020:120).

Dijitalleşmeyi, hızlı ve dönüştürücü bir etki sahası olarak yeni bir durumun içinde inşa edilen gelişmeler olarak tanımlamak mümkündür. Gelişen ve değişen küresel süreçte, dijitalleşme günlük hayatın içinde oldukça önem kazanan bir yapıya dönüşmüştür/dönüşmektedir. Dolayısıyla, günlük yaşamın içinde herkesin her an her yerde erişebildiği bir şekle sahiptir (Türker, 2018:213).

Dijitalleşme, gündelik hayatta kısa sürede farklı birçok olayın gerçekleşebilmesini sağlar (Aydoğan, 2014:22). Zaman ve uzam düzleminde gerçekleşen bu değişim erişilebilirlikten doğan ve herkes için kullanılabilirlik sağlayan bir özelliktir. Söz konusu özellikler, hayatın olağan akışı içerisinde büyük bir değişim yaratmaktadır. Geleneksel olandan farklı bir yapı olan dijital, yeni etkileşim ve iletişim şekli içinde var olan yeni gelişmeler olarak hayatın olağan akışının değişim ve dönüşümüne neden olmaktadır.

Dijital olanda iletişim süreçlerinden doğan ve iletişim araçları içinde şekillenen verilerin, ayrıştırılabilmesi ve bir arada kullanılabilmesi için bir elektrik sinyali dolaşımı oluşturulmaktadır. Yeni bir elektronik ortamda dolaşım sağlamak, etkileşimi de beraberinde getirmektedir. Dolayısıyla, iletişim araçları içinde ses, veri, görüntü, video paylaşımı olmaktadır. Bununla beraber paylaşım yapılan içeriklerin üretimine de imkân tanınmaktadır (Değirmencioğlu, 2016:593-594).

İletişim ve etkileşim süreçleri devamlılık ve dinamizm içermektedir. Dolayısıyla bu dinamik süreçler, yeni gelişmeler eşliğinde kendi paradigmalarını yeniden şekillendirebilmektedir. Bu anlamda, dijitalleşme için iletişim ve etkileşim ilişsisi ile birçok alanı etkileyen bir süreçler bütünüdür denebilir. Dijitalleşmenin getirdiği dönüştürücü etkiler ile birçok eylem ve ilişki ağları dolaylı ya da doğrudan etkilenebilmektedir. Bu ilişkisel etki durumu, çoklu ve tamamlayıcı kombinasyonlara sahip olarak bilgi ve iletişim süreci olarak gerçekleşmektedir (OECD, 2017:9).

Dijitalleşme ontolojisi gereği, multidisiplinler olma özelliği göstermektedir (Verhoef vd., 2019:2). Çok fonksiyonlu faaliyetleri gerçekleştirme olanağı ile dijitalleşme kendi içinde yenilikçi yani yenilikçi teknolojilerin kullanımını yaygın hale getirmektedir. Bu anlamda, dijitalleşme, disiplinler arası işbirliğine hizmet sağlayan platform veya platformlar zinciri oluşturmaktadır (Pershina vd., 2019:1). Fiziksel dünyay1 çeşitli teknolojik altyapılarla yakınlaştıran dijitalleşme (Gebauer vd., 2020:1), yeni ve değişken bir sistem olarak, enformasyon teknolojilerine de katkı sağlayan bir durum oluşturmaktadır.

Dijitalleşme, dijital olarak teknik, örgütsel ve yönetsel yeniliklerle birlikte bir enformasyon teknolojisi paradigması oluşturmaktadır (Freman, 1988'den akt.: Castells, 2013:88-89). Bu paradigmanın beş temel fonksiyonu bulunmaktadır. Bunlar (Castells, 2013:89-91);

1. Enformasyon,

2. Yeni teknolojilerin yayılma özelliği,

3. Enformasyon teknoloji sisteminin ağ kurma mantığı,

4. Esneklik,

5. Teknolojilerin bütünleşmiş bir sisteme dönüşmesi.

Enformasyon teknolojilerinin varllğı ve gelişime yönelik dinamiği, bireylerin dayanışma ve işbirliği içinde olmalarının yanında, örgütlenme becerilerini de tetiklemektedir. Bu durum çeşitli değer ve amaçların paylaşıldığı bir ilişki zinciri olan "Enformasyon Toplumunun" oluşmasını sağlamaktadır (Sayımer, 2008:11-12). Bir dijital toplum ontolojisi olarak enformasyon toplumunda yer alan hususlara bakıldığında, öne çıkan değer ve bileşenler, yeniliklerin hızlı bir şekilde yayılması ve yeniliklerin ortaya çıktığı ortam ya da ortamlar kapsamında şekillendiği gerçeğidir (Güçdemir, 2015:14).

Castells (2013:89), enformasyonu temel alan dinamiğin enformasyon teknolojileri olduğuna işaret eder. Düşünür, enformasyonun bireysel ve kolektif durumlarda yayılmasını sağlayan yeni teknolojilerin etkisinin varlığını ve bu teknolojilerin sistematik olarak bir küme oluşturmasını sağlayan bir ağ kurma mantığının oluştuğu ifade eder. Bu anlamda, Castells'in ifadesinde yer alan ağ sistemlerinin varlığı, bu çalışmanın temel 
hususlarından biri olarak dijital durumlarda ağlar zincirini değerlendirmek ve bu rotada durum tespiti yapmak için bir temel sağlamaktadır.

Enformasyon ile ilgili faaliyetlerin yaygınlaşmasını sağlayan yenilikler arasında, sosyal ağlar yer almaktadır (Dilmen ve Öğüt, 2010:239). Bireylerarası ilişkilere yeni bir teori ve pratik katan sosyal ağlar (Alikılıç, 2011:35), sanal ortamda "topluluk" oluşturan bireylerin kolektif hareket etme, fikir ya da düşüncelerini paylaşma, yeni çözümler üretme gibi çalışmalarına yardımcı olmaktadır (Akyazı ve Ateş, 2012:181).

Bir ağ oluşturma faaliyeti olarak sanal ve dijital ortamlar sunan sosyal ağları, Castells'in ifadesinde yer alan "yerel ve küresel zincirlerle örülmüş A ̆ Toplumu” değerlendirmesini, dijitalleşme sürecindeki yeni gelişmelerin 1şı̆̆ı̆nda anlamak ve tartışmak mümkündür.

İnternet, bilgi ve iletinin bilgisayar yazılım sistemleri aracılı̆̆ıyla, zaman ve sanal mekânda iletilmesini, depolanmasını, işlenmesini mümkün hale getirmektedir (Slevin, 2007). İnternet teknolojisinin ilk kullanım özelliği olan Web 1.0 teknolojisi, bilgi ve iletiyi tek taraflı kullanma (içerik sahibi kurum, kuruluş ya da birey) seçeneği sağlamaktadır (Güçdemir, 2015:30).

Web 1.0 özellikli internet, sosyal ağ özelliğini karşıllklı etkileşim olarak desteklemediğini söylemek mümkündür. İnternet teknolojisinin ikinci nesli Web 2.0, etkileşimi mümkün hale getiren bir platform olma özelliğine sahiptir (O'Reilly, 2010). Web 2.0 ile oluşan toplumsal ağ siteleri, çevrimiçi olarak etkileşim ve birliktelik sağlamaktadır. Bunun yanında da bilgi ve iletiyi karşılıklı olarak paylaşma imkânı sunmaktadır (Güçdemir, 2015:31). Bu anlamda, internet kullanıcılarına ortak ve paylaşımlı bir sistem sağlayan (Sayımer, 2008:29) Web 2.0 teknolojisini, internetin sosyal ağ özelliğini kitleler tarafindan ortak, karşıllklı içerik üretimine imkân sağlayan bir teknolojik alt yapı diye tanımlamak mümkündür. Web 2.0 teknolojisi sayesinde kullanıcı aktif, internetin zengin dünyasını hem takip eden hem de üreten konumda olmaktadır (O'Reilly, 2010:225-226). Web 2.0'ın en önemli özellikleri arasında, farklı kaynaklarda yer alan yararlı ve kullanılabilir bilgiyi tek bir site altında birleştirmesidir. Kullanıcılar, Web 2.0 sayesinde, yeni nesil web zinciri halkaları oluştururak, istedikleri fotoğrafları yükleyebilir, anlatmak istedikleri sosyal içerikleri anlatabilir, ziyaret ettikleri siteleri çok sayıda insanla paylaşabilir hale gelmektedirler (Alikılıç ve Onat, 2007:902).

Web 2.0 teknolojisiyle birlikte değișen kullanıcı profilini sosyal ağların günümüzdeki haliyle yaygınlaşmasından çok önce tanımlayan Toffler, üreten tüketici "prosumer" kavramını ortaya koymuştur. Bu kavramı konu kapsamında değerlendirdiğimizde sosyal ağlar ile bireyler birer kullanıcı olarak hem içerik üretmekte hem de var olan içerikleri paylaşarak ya da onlarla etkileşime geçerek tüketmektedirler. Sosyal ağların bireylerarası iletişim süreçlerinde yoksunluk yaratacağına dair endişeleri içeren bakış açılarının aksine Toffler, bireylerarası etkileşimlerin bu ağlar sayesinde daha da güçleneceğini ve yeni ve güçlü bir birlik ruhu yaratılmasında etkin rol oynayabileceğini ifade etmektedir (Toffler, 1980:457).

Web 2.0 ile dijital dünya yeni bir değişim ve dönüşüm alanına sahip olmuştur. Web 2.0 sosyal ağ platformlarının artmasına olanak tanıma noktasında alt yapı sağlamaktadır. Sayısı artan sosyal a ğ platformlarının (Facebook, Twitter, LinkedIn, Instagram vb.) artmasına paralel olarak bu platformlarda varlık gösteren kişi sayısı da çoğalmaktadır. Bu artış, sosyal ağlar için yeni gelişmelerin de yaşanabileceğini göstermektedir: Kişiler tarafından oluşturulan içerikler ve bu içeriklerin sürekli olarak üretimi;

- Toplumsal katılim,

- İşlevsel paylaşım,

- Sürekli güncelleme,

şeklinde kategorize edilebilecek durumlar için ortam sağlamaktadır (Genç, 2010:482). Web 2.0, kişilere birbirleriyle etkileşim ve iletişim için teknik bir alt yapı sağlamaktadır. Bu alt yapı ile kişiler, toplumsal etkileşim mekânına kavuşmaktadır (Ö̈zdemir ve Çetinkaya, 2014).

Sosyal ağlar internet tabanlı, sanal toplumsal paylaşım ağları olarak (Toprak vd., 2014:28), eşzamanlı olma özellikleri ile 7/24 iletişim imkânı sağlamaktadır. Ortak kaynak üzerinden bağlantı sağlayan (Güçdemir, 2015:41) ve sanal olan uzam açısından her yere ulaşma imkânı veren sosyal ağlar, sınırlı sosyal hayatlara sahip insanlara da, toplumsallaşma, toplumla ilişki kurma olanağı sunmaktadır (Castells, 2013:480).

Bir dijital ağ yapısı içinde bu ağları kullanan ve bağlantı halinde olan kullanıcılar (Tonta, 2009:745), ortak paylaşım ilgisi ve ilişkisi dâhilinde belirli gruplar oluşturmaktadırlar. Bir araya gelen bireyler, "sanal topluluk" adı verilen bir sisteme entegre olarak çeşitli kullanıcı profilleri (açık, yarı açık, kamuya açı) 
oluşturabilmektedir. Bunun yanında anlık mesaj, çeşitli dosya, resim, video gibi paylaşım olanaklarına sahiptirler (Güçdemir, 2015:67).

İnternetin yaygın hale gelmesi sonucu sosyal ağlar, sanal mekân deneyimini farklı ortamlarda çeşitli etkileşimler şeklinde arttırmıştır (Castells, 2013:472). Bir dijital yapı olarak sosyal ağlar, bireylere çeşitli olanaklar sunmaktadır. İnternetin sunduğu yeni nesil çevrimiçi platformlarda kullanıcı olarak var olan bireylerin, kullanıcı olarak bu platformlarda var olma ve kimlik inşa etme süreçleriyle sosyal ağlarla sanal dünyanın yeni etkileşim çerçevesinin ontolojisi arasında ilişki vardır.

\section{SOSYAL AĞLARIN İŞLEVSELLİ̆İ VE ETKİLERI}

Castells, sosyal ağ akışlarının uzamının mekânsız olmadığını, ancak yapısal mantığının mekânsız olduğunu ifade etmektedir. Bu kapsamda (Castells, 2013:549);

"Akışlar uzamı elektronik bir ăga dayalıdır. Ancak bu ă̆, gayet iyi tanımlanmışsosyal, kültürel, fiziksel ve işlevsel özelliklere sahip belli mekânları bağlar. Bazı mekânlar değiş tokuş yapan, ăg dâhilindeki bütün unsurların rahat iletişimi için bir tür iletişsim limanı rolü üstlenen yerlerdir. Diğer yerler ă̆ın merkezleridir; yani ăgdaki belli bir kilit işlevin çevresinde yerelliğe dayalı bir dizi faaliyet ve örgütlenme kuran, stratejik açıdan önemli işlevlerin bulunduğu yerlerdir."

Sosyal ağların birçok işlevselliği ve bu işlevselliğin birçok etkileri bulunmaktadır. Aşağıda yer alan şekilde, sosyal ağların işlevselliği ve bu işlevselliğin etkilerine yer verilmiş̧ir (Kietzmann vd., 2011:243).

Şekil 1. Sosyal Ağların İşlevselliği ve Etkileri
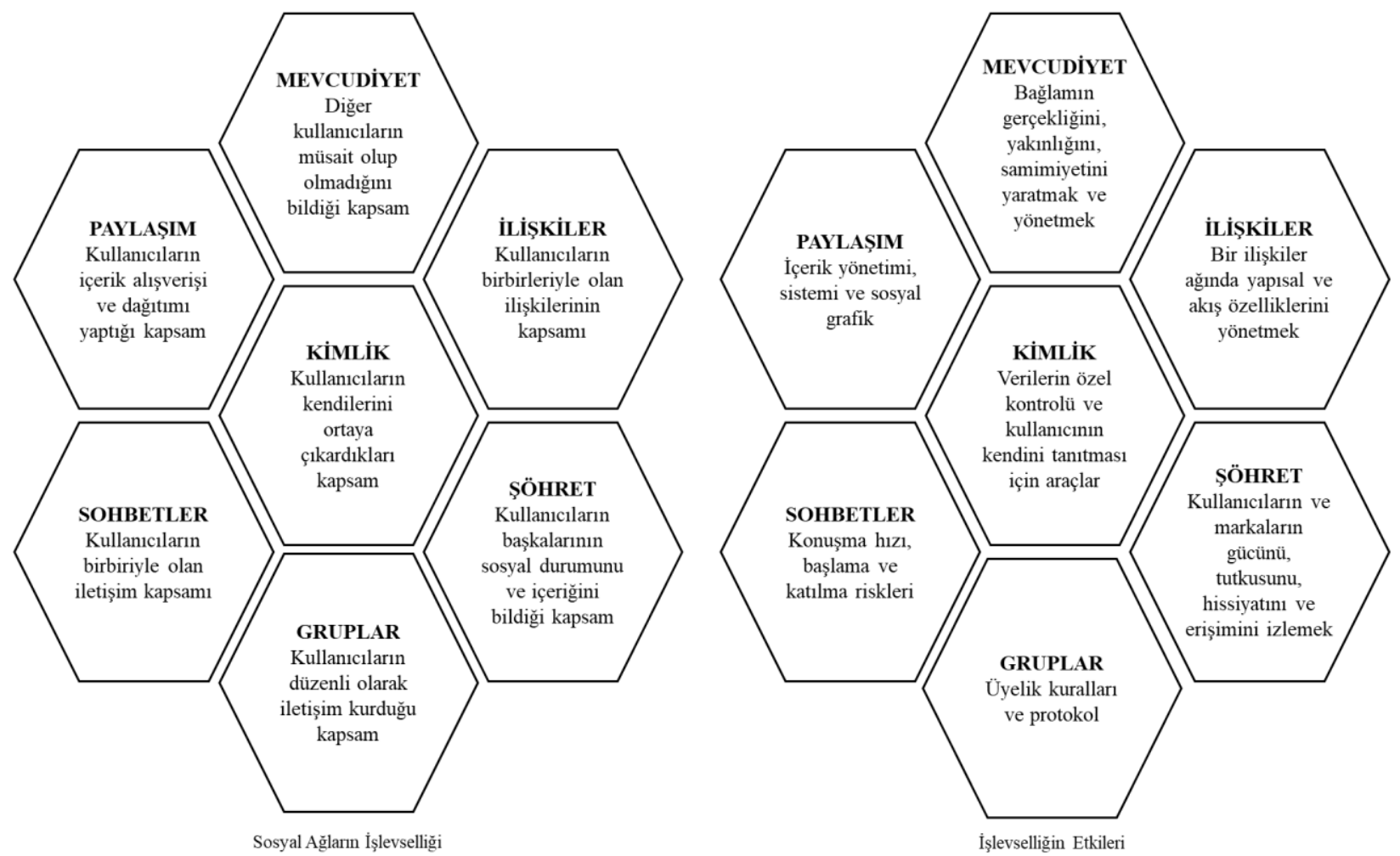

Kimlik işlevsel bloğu, kullanıcıların kim olduklarına dair bilgilerinin açıklandığı bir işlevi ifade etmektedir. İsim, yaş, cinsiyet, meslek, konum gibi bilgilerin açıklanmasını ve kullanıcıları belirli şekilde tasvir eden bilgileri içermektedir. Kullanıcılar, farklı söylem ve tercihlere sahiptir ve içeriklerinin özel kontrolünü kendi profilinde sağlayabilmektedir. Çerçevenin sohbet bloğu, kullanıcıların diğer kullanıcılarla ne ölçüde iletişim kurduğunu temsil etmektedir. Paylaşım bloğu, kullanıcıların ne ölçüde içerik ile etkileşim kurduğunu, değiştokuş yaptığını ve dağıtımını ifade etmektedir. Mevcudiyet bloğu, bir kullanıcının diğer kullanıcı/kullanıcılar için erişilebilir olup olmadığını ya da çevrimiçi olup olmadığını belirtmektedir. İlişkiler bloğu, diğer kullanıcılarla ne ölçüde ilişki kurulabileceğini iki veya daha fazla kullanıcı ile sohbet etme, sosyalleşme, buluşma, birbirlerinin arkadaş ve hayran listelerini görme ve ortak ilişkiler kurabilme potansiyelleri konusunda yönlendirici bir bağ kurma biçimini kastetmektedir. Şöhret bloğu, sosyal ağlarda kullanıcı olarak var olan tüm 
bireylerin tanınırlığını/bilinirliğini belirleyebilme ölçüsüdür. Grupların işlevsel bloğu, kullanıcıların toplulukları ve alt toplulukları ne ölçüde oluşturabileceğini temsil etmektedir (Kietzmann vd., 2011:243-247).

Sosyal ağların işlevselliği açısından mevcudiyet işlevi, kullanıcıların oluşturdukları profilde varlıklarını sergilemeleridir. Çevrim içi varlık sergileme olarak ifade edilebilecek olan bu durum kullanıcıların bulundukları mekânlarda konum paylaşımı yapmaları sosyal bir varlık olarak mevcudiyetlerini ifade etme yöntemi olarak ortaya çıkmaktadır. Sosyal ağlarda mevcudiyetin sergilenmesinde fiziksel mekânın kesişiminde yer alan konum tabanlı uygulamalarla, kullanıcılar farklı işlevsellikler yaratmaktadır. Bulunduğu mekâna ilişkin dijital veriyi paylaşan kullanıcılar, sosyal ağlarda da varlıklarını sergilerler. Kullanıcılar, sosyal ağlarda fiziksel mevcudiyetlerini dijital enformasyona dönüştürürler. Türkiye'de en çok kullanılan mevcudiyet paylaşım ağları, Foursquare ve Swarm'dır. Facebook, Twitter, Instagram vb. tüm sosyal ağlarda da konum paylaşma özelliği bulunmaktadır (Şahoğlu, 2018:259). Sosyal ağlarda kullanıcıların içerik alışverişi yaptıkları paylaşım işlevi, her sosyal ağın sunduğu farklı kullanım pratiklerine göre değişkenlik gösterir.

"Facebook, Youtube, Twitter, Instagram, LinkedIn şu an için ülkemizde sosyal ağların en popüler olanlarıdır. Her birinin amacı birbirinden bir ölçüde farklıdır: Twitter'da yazl, Instragram'da resim, Youtube'da video paylaşımlarına odaklanılmuştır; Facebook sosyalleşme ve boş vakitleri eğlenceli geçirmek için, LinkedIn ise profesyonel yaşamla ilgili paylaşımlar için daha uygundur" (Tosun, 2019:305).

Sosyal ağlarda kullanıcıların "fenomen" olma isteği, sanal şöhret denilen durumu ortaya çıkarmaktadır. İnsanlar Facebook ve İnstagram'da gündelik yaşamları ile ilgili fotoğraf paylaşmakta ve bu fotoğrafin beğenilmesinden hoşnut olmaktadır. Youtube gibi video paylaşım sitelerine video eklemekte, Twitter'a düşüncelerini yazmakta ve bu durumun insanlar tarafindan kabul görmesini talep etmekte ya da arzulamaktadırlar. Bu anlamda, sosyal ağlar çerçevesinde bir şöhret olgusu, herkes tarafından bilinme ve ünlü olma durumu oluşmaktadır. Aynı zamanda bireyin sosyal ağlarda şöhret olma kaygısı da ortaya çıkmaktadır. Birey, Facebook, İnstagram, Youtube, Twitter gibi sosyal ağlarda, var oluşunu, görünür olma ve başkalarının gözünde bir yer elde etme ihtiyacını şöhret olma olgusu ile gerçekleştirebilmektedirler (Yıldız, 2017:17-18).

Facebook üzerinde kullanıcılar gruplar işlevini düzenli iletişim ve etkileşim kurarak yerine getirebilmektedir. Bir katılımcı olarak kullanıcılar, açık ya da kapalı gruplara dahil olabilir, burada diğer kullanıcılarla bir amaç ya da hedef için ilişki işlevini gerçekleştirebilirler. Kullanıcı profilleri ile dahil oldukları grupları (aile, okul, iş, interaktif gruplar vb), kategorize ederek, durum güncellemesi eşliğinde ilişki işlevini paylaşım yaparak deneyimleyebilmektedirler (Yıldırım vd., 2018:48-49).

Kimlik işlevini ise İnstagram üzerinden örneklendirmek faydalı olabilir. İnstagram uygulamasıyla kullanıcılar kimlik/ kimliksel işlevlerinin inşalarını gündelik hayata göre şekillendirebildikleri gibi bürünmüş oldukları kişisel rolleriyle de (kendilerini özel olarak görmek isteyeceği durumlar) sergileyebilmektedir. İmaj yaratma çabası içinde de benlik sunumlarını maskeleyebilmektedirler. Manovich'in (2017) İnstagram'da imaj yaratma konulu çalışmasında bu durum üç içerik çerçevesinde değerlendirilmektedir. İçerikler, günlük, profesyonel ve tasarlanmış içerik olarak ele almaktadır. Bu üç içerik, gündelik hayattan farklı olarak kişisel rol, istek, arzu, olan ve olmak istenen kişisel rollere göre şekillenebilme özelliğine sahiptir (Manovich, 2017:42-49).

\section{SOSYAL AĞLAR VE ETKİLEȘIMM}

Sosyal ağlar, bireylerin kamuya açık ya da yarı açık profiller oluşturarak, kimlerle bağlantıya geçeceklerini seçebildikleri ve arkadaş listelerinin ve/veya bağlantı kurdukları kişi/kişilerin görünmesinin mümkün olduğu internet tabanlı servisler olarak tanımlanmaktadır (Boyd ve Ellison, 2007:211). Sosyal ağlar, sanal olarak sosyal ilişkilerin altyapısını oluşturmaktadır. Bu ilişkiler insanlar arasında oluşan yüzlerce zayıf bağın genişlemesi ve yoğunlaşmasını sağlar. İlişkiler sonucu ortaya çıkan etkileşim, fiziksel topluluklarda görülen etkileşimden farklı bir gerçeklikte ilerlemektedir. Söz konusu gerçeklik; zayıf bağlara dayanan, çok çeşitli hale gelmiş, uzmanlaşmış, sağlam bir etkileşimin etkin olmasıyla karşılıklılık ve destek üretebilen kişisel deneyim esasına dayanmaktadır (Castells, 2013:479-480).

Bir etkileşim ortamı olarak sosyal ağlar, internet tabanlı bir etkileşim ortamı sunmaktadır. Bu etkileşimin genel faaliyeti, internet üzerinde bir araya gelen bireyler eşliğinde gerçekleşmektedir. Çevrimiçi topluluklar internet üzerinde ilgi alanlarına göre bir araya gelebilmektedir (Genç, 2010:484).

Sosyal ağ platformları, kullanıcılar için birçok esnek kullanım imkânı sağlamaktadır. Kullanım esnekliği; bilgi iletimi, paylaşım yapabilme, ilişki içinde olma şeklinde gerçekleşir (Özmen vd., 2012:497). Sosyal ağ 
platformlarında, sanal olarak gerçekleşen bir etkileşim durumu yer almaktadır. Bununla birlikte bireyler, sanal uzamda, sosyal ilişkilerini ve sanal hayatlarını geliştirmektedir (Ekici ve Kıyııı, 2012:158).

Sosyal ağlarda, etkileşim yaratabilmek için sosyal ağ kullanıcısı kişinin, bir profil oluşturması ve farklı kişilerle bağlantı kurması gerekmektedir. Bu durum, sosyal ağlarda bir etkileşim-iletişim ekseni yaratmaktadır (Toprak vd., 2014:29). Bu durumun en önemli özelliği birçok kişiden birçok kişiye sağlanan etkileşim faaliyetidir (Memiş, 2015:210). Yeni yapı ve gelişmeler eşliğinde, sosyal ağlar, geleneksel ortamdan farklı bir iletişim ve etkileşim durumu sağlamaktadır. Geleneksel ortamda gerçekleşen iletişim ve etkileşim faaliyetlerini de sanal ortamlara taşımaktadır (Akar, 2010:108).

Kişisel etkileşimi arttırma çabası olarak ortaya çıkan sosyal ağlar, bireylere kendi etkileşimlerini yönetme firsatı sunmaktadır (Alikılıç, 2011:35). Bu kapsamda sosyal ağlarda yer alan etkileşimi anlamlandırma çabası için (Ariel ve Avidar, 2015:21-22);

- Katılımcıların deneyimlerine odaklanarak, etkileşim ile oluşan algıyla ilişkili değişken olarak,

- Katılımcıların bilgiyi birbirlerine aktarma yollarına odaklanarak,

- Bir ortamın teknolojik özelliklerine ve aktivite üretme kabiliyetine odaklanarak interaktif şekilde bir ortam karakteristiği olarak belirtilen bir anlam profili çizilmesi gereklidir.

Sosyal ağları kullanan insanlar arasında farklı duygu durum etkileşimleri gelişebilmektedir (Yıldırım, 2012:244). Bir etkileşim aracı olarak sosyal ağları, McLuhan'ın "araç mesajın ta kendisidir” ifadesi eşliğinde değerlendirmek ve elektronik iletişim ağ platformları olarak görmek gerekir. Sosyal ağları (Toprak vd., 2014:28), bir iletişim aracı olarak tanımlarken dijital ağ iletişimi çerçevesinde gerçekleşen kişisel/kullanıcı seçimleri olarak görmek mümkündür. Nasıl bağlantı kurabileceğini belirlemek, çevrimiçi iletişim esnasında oluşan anlık ileti ya da mesajın içeriğini yayınlamak ve çeşitli bildirimlerde bulunmak ya da bildirim almak sosyal ağların araçsallı̆̆ıyla ilgilidir (Sayımer, 2008:124).

Yeni medya ortamları olarak sosyal ağlar, katılım, etkileşim ve kullanıcı bağlantılı içerik üretimi de sağlamaktadır. Çevrimiçi içerik üretimli etkileşim dendiğinde, kullanılan ortamın sunduğu çerçevede değişen mesaj ve taşıdığı anlamların değişiminden bahsetmek mümkündür. Ortamın sunduğu etkileşim ilişkileri ve bireyin kendini tanımlama, anlamlandırma çabası üzerinde düşünülmesi ve tartışılması gereken önemli bir konudur. Paylaşım odaklı içerik üreticisine dönüşen bireylerin toplumla etkileşimi yeni ilişki ağları oluşturmaktadır. $\mathrm{Bu}$ durumda paylaşılan bilginin ve üretilen içeriğin şekillenmesinde ve paylaşılmasında kurulan etkileşimler önem taşımaktadır (Turan, 2014:99).

Bilgi üretme veya bilgi paylaşımı, sosyal ağlardaki etkileşimli ilişkilerden kazanılan bir tür sosyal sermayedir. Kullanıcı tarafından sağlanan içerik veya bilgiler sosyal ağın başarısı için kritiktir. Diğer geleneksel iletişim platformlarının aksine, çevrimiçi sosyal ağlar çok sayıda kişinin etkileşim ve ilişki kurmasını destekler. Sosyal ağ oluşturmanın önemli bir yanı, çevrimiçi bir sosyal ortamda farklı kişiler arasındaki etkileşimi içermesidir. Sosyal ağ siteleri, farklı web sitesi özelliklerini kullanarak bire bir veya birden çok çevrimiçi etkileşime olanak tanır. Kullanım, sosyal ağların sunduğu özellikler çerçevesinde bireylerin etkileşim ile ilgili algılarını etkileyebilir (Shipps ve Philips, 2013:37-38).

Etkileşim ve paylaşım içerikli temaları bir araya getiren sosyal medya uygulamalarını da kapsayan sosyal ağlar, belli birtakım dinamikleri içerisinde barındırmaktadır (Doğu vd., 2014:29). Söz konusu dinamikleri, geniş anlamda ele alan Whiting ve Williams 2013 yılında, kullanıcıların sosyal ağ kullanımlarını dikkate alarak detaylı bir araştırma gerçekleştirmişlerdir. Bu araştırma sonucunda elde edilen bilgiler doğrultusunda sosyal ağ kullanıcılarını ve kullanım amaçlarını farklı tema/temalar üzerinden açıklamaktadırlar. Bunlar (Whiting ve Williams, 2013'den akt.: Uluk, 2018:27-28);

$\checkmark$ Sosyal Etkileşim: Katılımcıların \%88'i, sosyal medya aracılı̆̆ıyla arkadaşlarıyla, aileleriyle, eşleriyle, iş arkadaşlarıyla, eski dost ve tanıdıklarıyla daha fazla iletişim kurduklarını ve sosyal medyanın onlara sosyal bir yaşam sunduğunu ifade etmektedirler.

$\checkmark$ Bilgi Arama: Katılımcıların \%80'i, sosyal medyayı ürünler, indirimler ve firsatlar hakkında bilgi edinmek ve etkinliklerden haberdar olmak için kullandığını belirtmektedir.

$\checkmark$ Zaman Geçirme: Katılımcıların \%76'sı, boş zamanları olduğunda veya sıkıldıklarında sosyal medyayı kullandıklarını söylemektedir.

$\checkmark$ Eğlence: Katılımcıların \%64'ü, sosyal medyayı oyun oynamak, müzik dinlemek ve video izlemek gibi eğlence amaçlı kullandıklarını belirtmektedir. 
$\checkmark$ Rahatlama: Katılımcıların \%60'1, kullanıcı profillerini gezmenin rahatlattığını ve gerçeklikten kaçış sağladığını düşünmektedir.

$\checkmark$ Fikirleri İfade Etme: Katılımcıların \%56's1, gönderileri, fotoğrafları, güncellemeleri beğenme ve yorum yapma ve başkalarının yorumlarını paylaşma yoluyla sosyal medyayı düşünce ve fikirlerini ifade etmek için kullandıklarından söz etmektedir.

$\checkmark$ İletişimsel Yarar: Katılımcıların \%56'sı, sosyal medyanın onlara "başkaları hakkında konuşacak" ve "onlara dedikodu yapacak" bir şeyler verdiğini söylemektedir.

$\checkmark$ Kullanım Kolaylığı: Katılımcıların \%52'si, sosyal medyaya erişimin her zaman ve her yerden oldukça kolay olduğunu vurgulamaktadır.

$\checkmark$ Bilgi Paylaşımı: Katılımcıların \%40’1, sosyal medyada kendisi hakkında durum ve fotoğraf paylaşmayı sevdiklerini belirtmektedir.

$\checkmark$ Başkaları Hakkında Bilgi Edinme: Katılımcıların \%32'si, başkalarının neler yaptığını görmek ve "gözetlemek" için sosyal medyayı kullandıklarını ifade etmektedirler.

Sosyal ağlarda etkileşim esnasında, kullanıcı ile diğer kullanıcılar arasında bir bağ oluşmaktadır. Bu bağlar farklı şekillerde sınıflandırılmaktadır. İlk olarak kullanıcının sosyal ağlarda sergilemiş olduğu eylemin diğer kullanıcılar tarafindan tekrar edilmesi durumudur. Ayrıca kullanıcının eylemi, diğer kullanıcıları da benzer eylemleri yapmak/yapmaları için harekete geçmelerini tetikleyebilmektedir. İkinci olarak, herhangi bir kullanıcının dâhil olduğu sosyal ağ profili içinde yer alan diğer kullanıcılarla ortak şeyleri sevmesidir. Üçüncü durum ise çevre faktörüdür. Bu çerçevede iki kullanıcının eylemleri, temel bir noktada birleşebilmektedir (Anagnostopoulos vd.'nden akt.: Vural ve Bat, 2010:3356-3357).

Sosyal ağlarda gerçekleşen etkileşimin en temel özelliklerinden bir tanesi, "sembolik" temalı bir ilişkinin var olmasıdır. Mesajların içeriğinde temsili bir gerçeklik söz konusudur. Burada mevcut olan, süregelen ilişkilerin sembolik ortamın gerçekliği ile örtüşmesidir. Gerçek bir etkileşim deneyimi yaşamaktan ziyade, bir deneyim yaşamış gibi bir durum ortaya çıkmaktadır (Castells, 2013:497-498).

Sosyal ağlarda gerçekleşen sembolik etkileşim içinde bireyler, gündelik yaşamdan farklı bir tutum takınabilmektedirler. Bu araçlar içinde kişinin bireysel olarak oluşturduğu statü, ünlü olma gibi faaliyetleri sanal olarak temsil edebilmektedir. Ayrıca sosyal ağ kullanıcısı bireyin, diğer kullanıcıların bağlantılarını gözlemleyebilmesi, bireylerarası ilişkilerin durumunu belirleyici bir fonksiyon oluşturmaktadır. Sosyal ağlar yani sanal ortamda toplumsal paylaşım ağları, gerçek yaşamdan farklı olarak olunmak istenen kişiye dönüşüm için bir araç görevi de görmektedir. Bu araçlar, sanal bir yaşam kurmak isteyen kişilere ulaşamadıkları yaşamı sunabilir. Karakterize edilmek istenen yaşamı hayal eden kişilerle arkadaşlık kurmak isteyen diğer kişiler, kişinin gerçek dışı özellikleri ile temasa geçebilmektedir. Sosyal ağ araçlarında ima edilen en önemli hususlardan biri, her şeyin göründüğü gibi olduğu durumudur (Toprak vd., 2014:30).

\section{SOSYAL AĞLARDA KİMLIKK}

Sosyal ağlarda kimlik oluşturma ve yönetme aşaması, bireylerin içinde bulunduğu ortamın sunduğu imkânlar çerçevesinde kimlik inşa etmesi anlamı da taşımaktadır. Sosyal ağlar, sosyalleşme alanlarıdır. Değişen ve dönüşen toplum düzeninde bireylerin kendilerini ifade edebilmeleri ve sosyal olan içerisinde varlı sahibi olabilmeleri için sosyal ağlarda bir üretim ve tüketim sürecine girebilmeleri gerekmektedir. Bir kimlik inşa etme sürecinde ortamın sunduğu imkânlar, birey üzerinde oldukça etkili ya da belirleyici rol oynamaktadır. Bu anlamda, fiziksel ortam ile inşa edilen kimlik süreci dâhilinde ve dişında sosyal ağlar, çeşitli ilişki seçenekleri sağlamaktadır. Sosyal ağ/ağlar üzerinde var olan bireyler, sosyal ağlar üzerinden kimliklerini de inşa etme sürecine girmiş bulunmaktadır. Bununla beraber, inşa etmek için zaman ve emek harcadıkları kimliklerini yönetmek bireyler için oldukça önemli olabilmektedir.

Sosyal ağlar, internet çağı ile birlikte toplumlarda yaşam tarzlarını ve gündelik hayat ilişkilerini değiştirmektedir. Bireyler, geleneksel kitle iletişim araçlarından farklı olarak, edilgen bir konumdan etken konuma geçmektedir. Kişiler, kendi toplumsal ilişkilerini sosyal ağlar çerçevesinde inşa ederken, kimlik üretim sürecine de girmektedir. Dolayısıyla, bir kimlik bağı kurmak ve oluşturmak için içerik üretimi gerçekleştirmektedirler (Özdemir, 2015:113).

Sosyal ağların bireyler ve toplum üzerindeki etkisine dair önemli bir tanım "Enformasyon Çă̆l: Ekonomi,

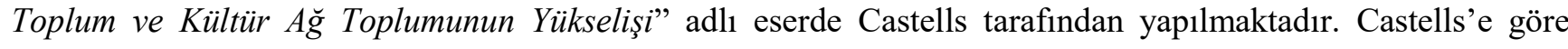


(2013:2), "Giderek evrensel, saylsal bir dili konuşan yeni bir iletişim sistemi, hem kültürümüzün sözcükleri, sesleri ve imgelerinin üretimini ve dağıtımın küresel olarak entegre hale getiriyor, hem de onlar bireylerin kimliklerinin ve halet-i ruhiyelerinin beğenilerine uygun klliyor" demektedir.

Sosyal ağlar ile hızlı değişimin etkileri bir etkileşim ilişkisi olarak, toplumsal boyutta kendini göstermektedir. Sosyal ağlarda var olmak aynı zamanda bir toplumsal örgütlenme biçimidir. Bu toplumsal örgütlenme biçimi, sosyal ağlarla birlikte toplumsal organizasyon ve toplumsal akış şemasının yeni durumları şeklinde gelişim göstermektedir. Toplumsal yaşamda başlayan yeni durumlar, iletişim faaliyetleri içinde hızlı değişim ve temel toplumsal dinamiklerin farklı alanlarda boy göstermesi ile açıklanabilir (Güneş, 2016:193). Bu alanlar arasında bireylerin kimlikleriyle kendini ifade etmeleri, çevrimiçi sosyal ağlarda görünür olmakla temellendirilebilir. Sosyal ağlarda görünür olmak ya da olabilmek, çeşitli kimlik ilişkilerini de beraberinde getirmektedir. Bu durum bireysel kimlik ve grup kimliği ekseninde detaylandırılabilir.

Bireysel kimlik, kişinin hayat içinde devam ettirdiği sosyal bir ilişki ağı kapsamında, oluşturduğu ya da oluşturmaya çalıştığı deneyimler olabilmektedir. Kişiler arası ilişkilerle inşa edilen bireysel kimlik, kendi içinde bir sosyal ağ çeşitlemesi yaratması ile kişiye, sosyalleşmenin kapılarını aralamaktadır. Bireysel kimliğin inşa süreci, sosyal ağ platformları çerçevesinde, teknolojik gelişmeler olarak yeniden ele alınma seçeneğini gündeme getirmiştir. Bu yeniden ele alınma ilişkisi, bireyin kendini sosyal ağ platformlarında yeniden sosyalleşme süreci içinde bulmasıyla sağlanmaktadır. Söz konusu sosyalleşme, bir birey ve bireyin kendi sosyal ağ çerçevesinde meydana getirdiği gruplarla ilintilidir. Sosyal ağlardaki ilişkiyi oluşturmanın verdiği kümelenme, sıklık, yoğunluk ve çoklanma ifadelerinin getirileriyle bir bilgisayar tanımlama işlemi olarak sürdürülebilir alanlar yaratılır. Sıklık, bireyin oluşturduğu bağlantı sayısına işaret etmektedir. Burada kişi, ne kadar sıklıkta bağlantı gerçekleştirmektedir sorusuna cavap aranmaktadır. Bağlantı sayısı ile bir sosyal ağ potansiyeli mevcudiyeti de yer almaktadır. Kümelenme, kişinin dâhil olduğu gruplar içinde bir çember yaratması olarak açıklanabilir. Kümelenme, bir ağ ilişkisinde, bütün ağı ifade eden bir terim olarak da ifade edilmektedir. Çoklanma, bireyin ilişki sayısını temsil etmektedir. Yoğunluk ise bir bağlantı ya da ilişkide gerçekleşen güç ve samimiyet temelli durumları ortaya koymaktadır. Sosyal ağlarda faaliyet halinde olan kişi ya da kişiler, bireysel kimlik ve grup kimliği için iş birliği ağları oluşturarak, ilişkinin niteliğini belirlemektedir (Acun, 2011:69-70).

Sosyal ağlar öncelikli olarak kullanıcılarına sanal kimlikler inşa etme firsatı vermektedir. İnsan kimliği üzerinde düşünülmesi gereken yeni durumlar yaratan sanal kimlikler, yeni sosyalleşme biçimi olarak sanal topluluklar etrafında iletişim kurma, kendini ifade etme ihtiyacı sağlar (Castells, 2013:476-477). Sanal ortamda kullanıcılar, oluşturdukları kimliklerle var olmaktadır. Bir kullanıcı diğer kullanıcılarla kolektif olarak içerik üretimi ve üretilmiş içeriğin tüketimi sürecine dahil olabilmektedir. Bu üretim ve tüketim süreci ortak bir paylaşım oluşmasını sağlar. Dolayısıyla bireyler tarafından bu kapsamda oluşan sanal kimlik etrafında paylaşımlar yayınlanabilmektedir (Turan, 2014:105).

Sosyal ağlar, bir sosyalleşme alanı sunabilmektedir. Bu sosyalleşme alanı, toplumsal olarak bir kimlik inşası sağlamaktadır. Bir birey sosyalleşme sistemi içinde, toplumsal olarak kendini inşa etmektedir. Bu anlamda birey, toplumda yer alan mevcut değer ve normlara uyarak bir sosyalleşme evresi geçirir. Söz konusu evrede kişiler "toplumsal kabul/onay" almaktadır. Bir toplumun kabulünde en muhakkak koşul, bir kimliğin inşasında bireyin sergilediği davranışlar olmaktadır. Aile içi ilişkilerden en dış sosyal katmana kadar birey kimlik inşasını tamamlamış olur. Böylece, karşılıklı sosyal ilişkilerde bir davranış mekanizması dinamiğinde, toplumsal etkileşim içinde kimliğini oluşturan bireyler/kişiler ortaya çıkmaktadır (Bakıroğlu, 2013:1048).

Sosyalleşme olgusunu sosyal ağlar nezdinde değerlendirmek için bir sosyal ağ platformlarını örneklendirmek faydalı olacaktır. Bu anlamda, sosyal ağlar içinde en çok bilinen ve tanınan araçlardan biri olan Facebook önemli bir örnektir. Facebook sosyal ağı ile kullanıcılar, temsili olarak kimlik inşası sürecini gerçekleştirebilmektedirler.

Sosyalleşme sürecinde yer alan kimlik inşasında olduğu Facebook sosyal ağında oluşan kimlik üretimi de kamusal bir süreçtir. Söz konusu durumun iki farklı boyutu olduğuna işaret edilir: "Kimlik duyurusu" olarak bireyin kendi kişisel kimliğini yansıttığı durum ve "kimlik ataması" yani diğer kişilerin kişiye yüklediği düşünceler. Bireyler, fiziksel ortamda ve diğer sanal ortamlarda kimlik üretim sürecini devam ettirmektedirler. $\mathrm{Bu}$ anlamda Facebook gibi sanal bir ortamda gerçekleşen iletişim içinde, yeniden yapılandırılan bir kimlik oluşturma süreci başlar. Bu süreç, oldukça karmaşık bir yapıda ilerlemektedir. Karmaşıklığın getirdiği iki aşamadan biri, kişilerin bedensel özelliklerinde istenmeyen durumlarını gizlemeleri ve bir gizli kimlik olarak, yeni anonim kimlik üretimine girmeleridir. İkinci durum ise anonim kimliğin ötesinde, bireylerin gerçek kimlikliğiyle oluşturduğu bağlantıların inşasıdır. Burada birçok faktör etkili olabilir. Aile, akraba, komşu vb. topluluklarla girilen ilişkinin neticesinde, kişiyi kendi gerçeklikleri içinde görebilmesi ve tanımlayabilmesi 
düşüncesinin var olması durumu bulunmaktadır. Bir çevrimiçi gerçek kimlik üretim sürecini inşa etmeye yönelik ilişki kurmak isteyen birey, bilgilerini açık ve şeffaf hale getirebilmektedir. Dolayısıyla Facebook örneğinde olduğu gibi, bireyler sosyal ăg platformlarında istedikleri (gerçek kimlik ve gerçek olmayan/anonim) kimliği üretebilmektedir (Toprak vd., 2014:103-104).

Kimlik inşasını, insanların deneyimlerini, tutarlı bir benlik duygusu içinde, seçici davrandıkları faaliyeti organize etme şekli olarak görmek ve bu duruma anlam verme süreci olarak değerlendirmek gerekir. Bu anlamda sosyal ağ platformlarında gerçekleşen etkileşim ve bu etkileşim yoluyla oluşturulan diyalog, müzakere ve performans süreçleri ile ilgili bağlantılar, kimlik için önemli bir gelişme olarak ilerlemektedir. Kimlik, yeni bir yapılandırma içinde farklı seçeneklerle kurulan dinamikler sonucunda inşa edilir ve bireylerin, diğer kişilerle bağlantı oluşturmasına bağlıdır. Oluşturulan bağlar, çevrimiçi sosyal ağlar çerçevesinde sanal olarak mekânsal bir düzlem bulur. Sanal mekânsal düzlemin olumlu getirileri bulunmaktadır. Bunun dışında, bireyin kendi içinde oluşturduğu bir karmaşıklık, birey ve diğerleri ile karmaşı ilişkilerin oluşması durumu gelişebilmektedir. Sorunun varlığı, bir karmaşık ilişki sürecinin yönetilmesi ile bağlantılıdır. Bir kişinin inşa etmeye çalıştığı kimlik bunalımı paradoksu, sosyal ağların sanal mekânsal düzleminde tam olarak etkileşimden doğan karmaşıklığ1 getirir. Bahsi geçen karmaşıklık, elektronik ortamda profesyonel ve kişisel kimlikler arasında meydana gelen bir aykırı düşünceler sentezidir. Birçok bilim insanın dikkat çektiği husus, karmaşıklıktan doğan bir kimlik bulanıklığı durumudur. Sanal ortamda gerçekleşen çevrimiçi etkileşimler, bir profesyonel kimlik ve kişisel kimliğin iç içe geçmesi sıkıntısı yaratabilir. Bu durumu belirgin şekilde yansıtan sosyal ağlar, kullanıcı için bir çelişki yaratabilmektedir. Kullanıcı, sosyal ağların doğasını iyi ayırt edebilmelidir. Bu anlamda, kişisel kimlik ve profesyonel süreç oluşturacak faaliyetleri ayrı ayrı gözden geçirmesi gerekebilmektedir (Gilpin, 2010:243).

Sosyal ağlardaki etkileşimsellik, bireyin sanal ortamda kimlik inşa etme süreçlerine çeşitli katkılarda bulunmaktadır. Bireyin toplumsal olarak kendini ifade edebilmesi, statü katmanları, ün vb. etkilerin iletişim şeklini tekrardan şekillendiren sosyal ağlar, bireyin kimlik oluşumu süreci için yarattığı farklılıklar olarak görülebilir. Bireyin sosyalleşme tanımını dönüşüme uğratarak ilerleyen bir kimlik inşası sağlamasıyla sosyal ağlar, Maslow'un ihtiyaçlar hiyerarşisinde yer bulan saygınlık katmanını bireylerin yeniden değerlendirmeleri için bir araç görevi görebilmektedir (Bakıroğlu, 2013:1053).

Saygınlık katmanı bireyin kimliğine ilişkin bilgilerle alakalıdır. Kimlik anlatısının en önemli unsurları arasında, kullanıcı kişinin sosyal hesaplara yüklediği profil fotoğrafı olabilir. Buna ek olarak kişinin konum bilgisi ve ne yaptığı (mesleği, okuduğu okul, hobileri vb.) ile ilgili detaylar da önemli etmenler arasındadır. Yine bu duruma örnek olarak, Facebook örneği üzerinden temellendirme yapılabilir. Kullanıcının kişisel sayfasında, internet tabanlı bir konum tespiti yapılabilmektedir. Kullanıcıya "ne yapıyorsun?" sorusu sosyal ağın temelinde yer alan (Facebook örneği temel alınarak) bir sistemle iletilmektedir. Bağlantı olarak duygular (mutlu, neşeli vb.), izlemekten hoşlandığı içerikler (film, dizi, program vb.), dinleme (pop, rock müzik vb.), oynama (çeşitli spor oyunları) gibi alt başlıklar, kişilerin kendi kişisel gereksinimleri ve isteklerine göre doldurulabilmektedir. Haliyle, bir sanal ortamın gündelik yaşam faaliyetlerini belirlemede etkili olduğu durumlar ortaya çıkmaktadır. Facebook örneği içinde fotoğraf paylaşımı, konum ve ne yapıyorsun sorusu eşliğinde kişiler; kendi istekleri, beklentileri ve bulundukları sanal sosyal ortama ayak uydurma doğrultusunda bir çeşitleme yapabilmektedir (Özkan, 2014:245-252).

Sosyal ağlar, kullanıcılar için gerçek yaşam ile sanal ortam arasında, bir kimlik durum tespiti yapabilme firsatı da vermektedir. Özellikle gerçek kimliklerin sergilenmesi dışındaki olan diğer durumlar olarak, interaktif ortamda kimliklerin gizlenebilmesi ve farklı kimliklerle paylaşım yapılabilmesi, sanal dünyada gizlilik olgusunu oluşturmaktadır. Bu sınırsız etkileşim imkânı dâhilinde kullanıcılar "gizli" kimliğini ön plana çıkararak daha özgür ve serbest (sorumluluk duygusundan uzak) bir şekilde hareket edebilmektedirler. Kimliğini gizleyen kullanıcılar içlerinden geçen görüş ve düşünceleri rahat bir şekilde paylaşabilmektedirler (Kırık, 2012:89). Dolayısıyla, sözü geçen ifadeyi, gerçek kimliklerin dışında gizli bir kimlik durumu ortaya çıkabilecek özellikte ilişkilerin inşa edildiği, sosyal ağ platformları içinde, kimliksel değişimin yaşanabileceği bir durum değerlendirmesi olarak düşünülebilir.

Çevrimiçi platformlar olarak sosyal ağlar, bireylerin kimliklerini maskelemesini sağlayabilmektedir. Bunun yanında kullanıcı olarak bireyler, kimliklerini olmak isteyeceği kişilere dönüştürebilmektedir. Bu noktada sanal sohbet ortamlarında kullanıcılar, "anonim olma" özelliğinden faydalanarak, kimliklerini maskeleyebilir ve profillerini olmak isteyeceği kişilere göre inşa edebilirler. Facebook ile ilgili yapılan bir araştırmada, bireyler kullanıcı olarak başka biri gibi davranma eğiliminde olabilmektedir. Araştırma çerçevesinde, gündelik hayattan farklı olarak çevrimiçi dünyada yeni ortaya çıkan kimlik dürtülerinin "monolotik" (tekdüze) olmaktan çıkıp, çevrimiçi öz sunumların ya da benliklerin çeşitlilik kazandığı da söylenmektedir (Zhao vd., 2008:1817-1819). 
Kimlik, benlik kavramının önemli bir parçasıdır. Benlik kavramı, bir kişinin bir nesne olarak kendine ilişkin düşünce ve duygularını kapsamakla beraber kimlik, benliğin başkaları tarafından tanındığımız kısmıdır (Zhao vd., 2008: 1817).

Günlük yaşamda benliğin sunumu (Goffman, 2009), bireyin kendini ve yaptıklarını nasıl sunduğu, başkalarının kendisiyle ilgili izlenimleri nasıl yönlendirdiği ile ilgili olmaktadır. Goffman’a (2009) göre, benliğin sunumu performans ile başlamaktadır. Bir kimsenin belli gözlemciler önünde bulunduğu süre boyunca gösterdiği faaliyetlerdir. Performansin en temel kavramlarından biri vitrindir. Vitrin, performans sırasında kasitlı ya da kasıtsız bir ifade şekli olarak kullanılmaktadır. Vitrinin standart öğelerinden biri settir. Set, genellikle kişinin ifade araçlarının görsel yönlerini anlatmak için kullanılmaktadır. Sahne, ortam, fiziksel unsurlar ile set arasında ilişki söz konusudur. Burada oyuncu kavramı benliğe dâhil olmaktadır. Oyuncu, kişisel vitrinle (boy, yaş, kilo, cinsiyet, köken, imaj, jest, mimik) farklı zaman ve mekânlarda kendisini ifade edebilmektedir. Temel bir tanım olarak kişisel vitrin görünüş ve tutum olarak değerlendirilebilmektedir. Görünüş oyuncunun toplumsal statüsü, tutum oyuncunun mevcut durumda oynamayı beklediği rol olabilmektedir. Set görünüş ve tutum arasına giren bir unsurdur. Vitrin, kolektif temsil olarak önceden belirlenmiş bir rolün sergilenmesine ön ayak olan belirli yer anlamına gelebilmektedir. Oyuncular; performans, vitrin, set unsurları ile dramatik canlandırma gerçekleştirerek karş1lıklı bir etkileşim yaratabilmektedir (Goffman, 2009:15-41).

Goffman günlük yaşamı tiyatro ile özdeşleştirmektedir. Bu anlamda kişileri karş1lıklı ilişkileri, zaafları, kaygıları, sahtekârlıkları ve ihtiyaçları ile değerlendirmektedir. Tiyatroda oluşan bir gösteri, planlı ve oyun olma durumu açıkça belli edilmişken günlük yaşamda yer alan oyunlar kendiliğinden ve sıradan olarak belirtilmektedir. Hayatın tümü tiyatro sahnesine benzer durumlarda kişiler, farklı yerlerde farklı rollere bireysel olarak ve takımlara dâhil olarak bürünebilmektedir. Günlük yaşamda asıl amaçlardan biri, kişinin benimsemiş olduğu roller çerçevesinde kendini sunduğu ölçüde karşı tarafi etkileyebilmesidir (Hülür, 2017:337-338). Bir kimlik inşası olarak sosyal ağlar, günlük yaşamda farklı benlik sunumu sağlayabilmektedir. Bu anlamda sosyal ağ kullanıcıları olan bireyler, çoklu benlik durumlarıla çoklu sosyal kimliklere bürünebilmektedirler. Çeşitli ortamlarda gösterdikleri çoklu benlik durumlarını kendilerini kabul ettirmek için stratejik olarak sergiledikleri çoklu sosyal kimliklerini (Özdemir, 2015:115) sosyal ağlarda kolaylıkla sergileyebilmektedirler.

Kullanıcılar sosyal ağlardaki ilişkilerini kimlik inşası çerçevesinde stratejik olarak Goffman'ın (2009) maske ve tiyatro sahnesi metaforu ile ilişkilendirebilmektedirler. Bu durum İnstagram üzerinden örneklendirilebilir. İnstagram; sosyal, kültürel, çevresel konular hakkında kullanıcıların etkinlikleri noktasında derinlemesine bilgi edinmeye yardımc1 olan bir sosyal ă̆ olmaktadır (Hu vd., 2014:1). İnstagram'da paylaşılan içeriğin karakterizasyonu değişkenlik gösterebilmektedir. Fotoğraf, video, yorum, favori, güncelleme, akış, gönderi gibi etkinlik ya da faaliyetler kullanıcılar tarafindan sınıflandırılabilmektedir. $\mathrm{Bu}$ etkinlik veya faaliyetler çerçevesinde İnstagram, sosyal farkındalık sağlayan bir araç olabilmektedir. Kullanıcılar, arkadaş oldukları diğer kullanıcılarla simetrik ilişkiler geliştirirken, arkadaş olmadıkları kullanıcılara karşı asimetrik ilişkiler oluşturabilmektedir. Kapalı ve açık ilişkiler sayesinde kullanıcı kendi profilini istediği stratejik sergileme hususunda maskeleyebilmektedir (Hu vd., 2014:1-3). İnstagram üzerinde kullanıcılar kimlik inşalarını bürünmüş oldukları rolleriyle de sergileyebilmektedir. Özellikle imaj yaratma çabası içinde bir maskeleme hususu sağlayabilmektedirler.

\section{SOSYAL AĞLAR İLE DEĞERLER İLISSKİSI}

Sosyal ağlar, bireyler arası ilişkileri yeniden şekillendirmektedir. Sanal kimliklerle etkileşime giren kişiler, sosyal ağlara özgü davranışlar gerçekleştirebilmektedir. Bu hususta ortaya koydukları durum, bir değere ilişkin anlamlar taşımaktadır. Değerler, bireylerin davranış ve temel ilkelerini şekillendiren bir ifade şeklidir. İfade şekli olarak, bireylerin davranışlarına temel inanç sistemleriyle rehberlik eden özgün bir yapısı vardır. İstenilen, arzu edilen ve gerçekleştirmek için çaba harcanan eylemlerin kararı, değerler 1şı̆̆ında verilebilmektedir (Halstead ve Taylor, 2000:169).

Sosyal ağların kullanımı ve kullanım amaçları, kişiden kişiye değişkenlik gösterebilmektedir. Kişiler arası ilişki içinde değişkenlik gösterebilmesi, çok çeşitli faaliyetlerin kullanımına imkân vermesiyle gerçekleşmektedir. Çok çeşitli kullanım özelliklerini ve birçok disiplini bir araya getirebilme özelliği ile sosyal ağları, geniş topluluklara erişim yaratma aracı olarak görmek mümkündür (Usluel vd., 2014:2). Bu anlamda, sosyal ağlarda gerçekleşen etkileşim ilişkisi içinde, kişilerin oluşturduğu geniş bir değerler ilişkisi etkisini yansıttığını söylemek mümkündür. Bu ilişkiler zinciri sosyalleşme faaliyetlerinden oluşur. Sosyalleşme, sosyal ağ araçlarının dolaşımı çerçevesinde bir bağlam bulmaktadır (Yeğen, 2013:131). Bu bağlam ile bir araya gelen bireyler, bir değer ya da değerler faaliyeti çemberi oluşturabilmektedir. Böylece, oluşturdukları çemberi, kendi 
içerik üretimleriyle yayınlar hale gelen birer sosyal ağ temsilcisi olarak hareket edebilmektedirler (Köseoğlu, 2012:58).

Dünya genelinde dijitalleşmeye dair verileri sunan "We Are Socials"'1n 2020 Y1lı Raporu'na göre, dünya genelinde 7.75 milyar insan internet kullanmakta, 3.80 milyar insan ise aktif olarak sosyal medya platformlarında varlık göstermektedir. 2019 yılında internet kullanan kişilerin sayısı 7.67 milyar, sosyal medya kullanıcıları ise 3.48 milyardır. Aktif internet ve sosyal medya kullanıcıların oldukça önemli sayılara ulaşması ve artışa devam etmesi, sosyal ağların popülerliğini gözler önüne sermektedir.

Sosyal ağ sitelerinin popülerliği ve artan insan sayısına paralel olarak, sosyal ağlar ile bilgilendirme ya da paylaşım yapma isteğini ortaya çıkmaktadır ve var olan isteği arttırmaktadır. Bireyler, sosyal ağ sitelerinde paylaşım yaptıklarında, kendi tutum ve davranışlarına göre gerekçeli eylem oluşturmaktadırlar. Davranışlar ya da tutum temelli eylemleri, etki yaratma fonksiyonu ile dolaylı olarak ifade etmeye meyillidirler. Burada söz konusu bireylerin kişilik/kişilikleri içinde inşa ettikleri, sosyal, duygusal, deneyimsel ve motivasyon kaynaklı bireysel farklılıklar şekillenebilmektedir. Bir kişiyi diğer kişiden ayıran kişilik fonksiyonu içinde, işlevsel şekilde anlam kazanan, kişinin kendi yarattı̆̆ öznel ifadelerdir. Bu öznel ifadeler, kişinin kişilik özellikleri içinde yer alan bir bütüne işaret eden deneyim ve davranış kalıpları olarak; bilinçli ve bilinçsiz şekilde ortaya çıkabilmektedir. Ayrıca arzular, görüşler, istekler, korkular eşliğinde de bir biçim kazanabilmektedir. Bu durum geniş çapta kişilik ilişkisi içinde kendi değerlerini yaratması için sosyal ağ sitelerinde yerini bulabilmektedir (Gvili vd., 2019:1-2).

Bireyler, hayatlarında yer alan aktivite ve etkinlikleri bir bağlantı ile paylaşmak isterler. Bu istek içinde yatan temel durum, hayatlarına katmak istedikleri değer ile ilişkilendirilir. Bunun nedeni, hayatlarında yer alan faaliyetlerin, belirli bir ihtiyacı ve gereksinimi karşılamasıdır. Sosyal faaliyet olarak belirli bir sosyalleşme ilişkisi içinde şekillenen değerler, bireylerin bir araya gelmesi şeklinde gerçekleşmektedir. Bireylerin bir araya gelme durumu, sosyal ağlar içinde, teknolojik yapısal bağlarla üretilebilmektedir. Haliyle, sosyalleşme ile üretilen sosyal aktivite ilişkisi, bir üretim modeli ve aracı olarak sosyal ağların gelişmiş/geliştirilmiş çalışma yapısıyla yeniden hayat bulmaktadır. Özellikle sosyal ağların bilgi ve iletişim teknolojisi etkileşimi, ortak temel dağıtım zinciri görevi görmesiyle, bir araya gelme bağlantısı sağlamaktadır. Söz konusu bağlantı ile sosyal ağların üyesi olan bireyler, hayat içinde ilişkilendirdikleri, sosyal aktivitelerine 1şık tutan değerleri canlı tutabilmektedir (Calastri vd., 2017:16-17).

Sanal ortamlar, toplumsal paylaşım platformu özelliği taşımaktadır. Günlük yaşamda sergiledikleri değerleri, davranışlarıyla ortaya koyan bireyler, sanal ortamda üretilen paylaşımlar ve beğeniler gibi içeriksel etkileşimleriyle sergilemektedirler (Karaduman vd., 2017:253). Kullanıcı olan bireyler, sanal mekânlar aracılığıyla birçok davranış kalıbını ortaya koyabilmektedir. Kullanıcı, diğer kullanıcılarla sorunlarını konuşabilir, fikir alışverişi yapabilir, duygusal destek alabilir, aşk ya da sevgi gibi duygusal ilişki içinde olabilir (Tunçel, 2014:70). Kısacası, toplumsal olarak kabul görmüş değerler nezdinde, sanal ortam kullanıcıları davranışlarını, zaman ve mekân sınırı olmadan gerçekleştirebilir. Bu anlamda, "sosyal ağ platformlarında faaliyetlerini gerçekleştiren ya da davranışlarını sergileyen kullanıcılar, bu ağlarla bir değer ilişkisi kurmaktadırlar" ifadesini kullanmak yerinde olacaktır.

Bir sosyal ağ yapısı açısından değerler ilişkisini düşünmek, toplumsal paylaşım ağları olarak kullanıcıların kendilerini ifade edebildikleri, kimliklerini istedikleri şekilde yönlendirebildikleri içeriklerin üretimi (Toprak vd., 2014:108) açısından, bir paylaşım mekanizması eşliğinde değerlendirilebilir. Sanal ortamlar içinde paylaşılan ileti ya da mesajın, bir etki alanı bulunmaktadır. Bu anlamda, bireylerin sanal ortamda paylaşımlarının yansıttıkları değerler, oldukça önemli bir ilişki ağını oluşturmaktadır. Bu değerlerin farkında olunması ve bilinçli bir şekilde sanal ortamın kullanımı, toplumsal yaşama önemli katkılar sunmaktadır (Karaduman vd., 2017:253).

İnternet tabanlı uygulamalara kullanım pratikliği sağlayan sosyal ağlar, paylaşım kültürü etkileşimi üzerine temellendirilmiş bir halka oluşturmaktadır (Çağlar, 2014:487). Halkayı inşa eden ve onu sürekli olarak yapılandıran bireyler, birçok gündelik hayat deneyimini sosyal ağlara taşımaktadır. Dolayısıyla, ağ tabanlı ortamların gündelik yaşamın bir parçası haline geldiğini söylemek mümkündür. Gündelik yaşam pratikleri içinde inşa edilen değerler, sosyal ağ platformlarında yeniden şekillenir. Çevrimiçi olarak sanal ortamda yaşam, kullanıcıların anlamlandırmalarıyla devam etmektedir. Burada bir benlik değerlendirmesi mevcuttur. Kişi kendi benliğine ilişkin değerli olarak gördüğü, beklenti, tepki, anlatı gibi birçok ifadeyi oluşturabilmektedir (Özkan, 2014:245-250).

Sosyal ağlar, birçok ilişki ve iletişim zinciri oluşturmaktadır. Söz konusu ilişki ve iletişim zinciri içinde bireyler, kullanıcı profilleri ile kişisel bağ ve ilgilerini diğer insanlara sunabilmektedirler (Vural ve Bat, 2010:3356). 
Gündelik yaşam içinde oluşan bireyler arası bağlar, gündelik yaşam deneyimleri ile inşa edilmektedir. Gündelik yaşam pratiklerini sanal ortam dolaşımına sokan sosyal paylaşım ağları (Özkan, 2014:245), bir değer ve değerler sistemi için yeni sürdürülebilir alanlarını oluşturmaktadır. Sosyal paylaşım ağlarında kullanıcılar, mevcut profilleri içinde sosyal ağ kullanımını sürdürülebilir kılmak, kullanıcılarının bu ağlara atfettikleri değer/değerler üzerinden açıklanabilmektedir. Bir sosyal paylaşım ağı kullanım pratiği içinde sosyal ağlarla ilişkilendirilen değerler, sosyal ă̆ kullanımı açısından oldukça önemlidir. Bireyler sosyal ağları, belirledikleri kullanım amaçları doğrultusunda şekillendirmektedir. İnsanların sosyal ağları neden kullandıkları, kullandıkları bu platformlara ne tür değerler atfettikleri aşağıdaki tabloda açıklanmaktadır (Hallikanien, 2014'den akt.: Kaymas, 2016:324).

Tablo 1. Sosyal Ağlarda Kullanıcı Değer Kategorileri

\begin{tabular}{|c|c|}
\hline Sosyal Ă̆ / Kullanıcı Değer Kategorileri & Değer Tanımları \\
\hline İşlevsel Değer & $\begin{array}{l}\text { Kullanıcının, sosyal medya ağlarını kullanma sürecinde } \\
\text { amaçladığı ve amacının gerçekleştiği değerdir (benlik sunumu } \\
\text { çerçevesinde bireyin kim olduğunu ifade edebilme ve diğer } \\
\text { insanlar tarafından nasıl göründüğünü anlama amacı gibi). }\end{array}$ \\
\hline Sosyal Değer & $\begin{array}{l}\text { Sosyal medya ağlarının kullanılmasıyla, kullanıcının amaçladığ } 1 \\
\text { sosyal gruplarla bütünleşmesini içeren değerdir. (Örneğin; } \\
\text { kişilerarası ya da grup etkileşimi kurmak gibi) }\end{array}$ \\
\hline Duygusal Değer & $\begin{array}{l}\text { Sosyal medya ağlarının kullanılmasıyla elde edilen duygusal } \\
\text { tatmin ve bu amaçla kullanımın sürdürülmesidir (kullanıcıların } \\
\text { duygusal reaksiyonlarını ifade eden paylaşımlar yapması gibi). }\end{array}$ \\
\hline Bilişsel Değer & $\begin{array}{l}\text { Sosyal medya ağlarının kullanılmasıyla elde edilen bilgi, merakın } \\
\text { giderilmesi, yeniliğin sağlanmasıdır (okuyucu, dinleyici ve } \\
\text { izleyici olarak bilgi akışı sağlamak gibi). }\end{array}$ \\
\hline Koşulsal Değer & $\begin{array}{l}\text { Sosyal medya ağlarının kullanılmasıyla, kullanıcının bir koşulu ya } \\
\text { da durumu yerine getirmesidir (doğum günü için kutlama } \\
\text { mesajları ya da yeni yıl mesajları gibi). }\end{array}$ \\
\hline
\end{tabular}

Kaynak: Hallikanien, 2014'den akt.: Kaymas, 2016:324.

Yukarıda yer alan tabloda, sosyal ağ kullanıcı değerlerine ilişkin kategorileştirme açıklamalarıyla sunulmuştur. $\mathrm{Bu}$ çerçevede sosyal ağ kullanıcıları için belirli amaçlar doğrultusunda sosyal ağları kullanmak ve bu kullanım amacını inşa etmek, işlevsel değer olarak belirtilmektedir. Sosyal ağlar içinde kullanıcı kişinin bir sosyalleşme sürecini inşa etmesiyle ilgili ikinci değer sosyal değerdir. Duygusal, bilişsel ve koşulsal değerleriyle sosyal ağlar etkileşim, kimlik ve değerler ekseninde birey ve toplumu etki alanı içerisine alan bir bağ kurar. Dolayısıyla bu tablo ile ilgili, sosyal ağların sunduğu değerler ve imkânlarla birlikte bireyin topluma ve kitlelere daha hızlı ulaşabilmekte, etkileşim içerisine girebilmekte ve bu ağların sunduğu değerleri önemsemekte olduğunu söylemek mümkündür.

\section{SONUÇ YERINE}

Küresel ölçekte bir işlerlik oluşturan dijitalleşme süreci ontolojik yapıda incelendiğinde, çeşitli değişikliklerin öncülügünü üstlendiğini söylemek mümkündür. Çok fonksiyonlu bileşenleriyle farklı eylem, durum ve etki yaratabilme imkânına sahip olan dijitalleşme, insan ilişkilerine ve gündelik hayatın işlerliğinde birey, toplum ve organizasyonların etkileşim ve iletişim süreçlerini yeni bir boyuta taşımıştır. Bu boyut sosyal ağlar ile çeşitli işlevsellik kazanmaktadır.

Kullanıcıların sosyal ağlar içinde kimlik inşaları ve sosyal ağlar tarafından bireysel öznelliğin dijital inşasının nasıl oluşturulduğu düşünüldüğünde, söz konusu sosyal ağları kullanacak kişilerin ilk olarak sosyal ă̆ platformlarına üye olmaları ve bu platformlarda bir profil oluşturmaları gerekmektedir. Bu kapsamda sosyal ağlarda bireyler özne olarak var olmaları noktasında yönlendirilmektedir. Oluşturulan profillerle ve paylaşılan iletilerle ağlar üzerinden kimlikler inşa edilmektedir.

Sosyal ağlar üzerinde kimlik inşası içinde kurulan bağlar, farklı ilişki seçeneklerini oluşturmaktadır. Bir günlük yaşam ilişkisi içinde bireylerin oluşturduğu bireysel kimlik ve grup kimliği, sosyal ağ platformu ekseninde yeni dinamik yapıları da beraberinde getirmektedir. $\mathrm{Bu}$ yeni dinamik yapıları şekillendiren ve sosyal ağlar 
aracılığıyla oluşan işlemlerle, bireyin kendi ilişki ağlarını ördüğü bireysel ve grupsal kimlik ilişkisinin niteliği belirlenmektedir.

Sosyal paylaşım ağları, insan ilişkilerinde bir etkileşim unsuru yaratan platformlar zinciri olarak görülebilmektedir. Burada sosyal ağlarla inşa edilen bir etkileşimden bahsedilmektedir. Mcluhan'ın (1994), "aracın yapısı ya da şekli, mesajın içeriğini belirlemektedir" ifadesinden yola çıkarak, etkileşimin gerçekleşmesinin sosyal paylaşım ağlarının yapısına göre şekillendiğini söylemek mümkündür. Bununla beraber, bir etkileşim faaliyeti olarak sosyal paylaşım ağları ilişkisinde bireyler, kullanıcı olarak kendi belirledikleri içerikleri üretebilmektedir. Kendi fonksiyonel etkileşim ilişkilerini inşa eden bireyler, bir kullanıcı için sosyal paylaşım ağlarının verdiği imkânları rahatlıkla kullanabilmektedirler.

Sosyal paylaşım ağlarında etkileşimin yolu kullanıcı kimliği ile açılmaktadır. Burada bireyler, bir kullanıcı kimliği inşa etmek durumundadır. Mevcut kimliği inşa ederken, fiziksel yaşamda var olan kimliklerini sanal ortamda yeniden sunabildikleri gibi sanal yaşamda gizli kimliklerle de var olabilmektedirler. $\mathrm{Bu}$ farklılık fonksiyonel olarak kullanıcı kimliklerini inşa etme süreçlerini, diğer kullanıcılara göre şekillendirebilmelerinden kaynaklanabilmektedir.

Sosyal ağların ortaya çıkardığı sonuçlardan en önemlisi, kullanıcıların oluşturdukları içeriklerle, içerik üreticisine dönüşmeleridir. Sosyal ağ platformlarına üye olan kullanıcılar geleneksel medyanın içerik üretim sistemi tarafından hazırlanıp paylaşılmış içerikleri tüketen tüketici rolünün dışına çıkmaktadırlar. Bu sayede yeni içerik oluşturma, paylaşma ve diğer kullanıcılar tarafından paylaşılan içeriğe katkıda bulunma çerçevesinde içerik üreticisine dönüşmektedirler. Toffler'ın üreten tüketici kavramıyla ifade ettiği gibi bireylerin, "bir zamanlar kendisine başkaları tarafindan yapılan hizmetleri yüklenmesi" şeklinde gerçekleşen sosyal ă̆ platformlarında var olması kişilerarası etkileşimler kurması, sosyal ağların sunduğu imkânlarla güçlenmekte ve etkinleşmektedir.

Sosyal ağlar kendi varlık sebepleri çerçevesinde, bireylere diğer bireylerle etkileşim kurma ve diğerleriyle ortak bir platformda var olabilme, paylaşım yapabilme imkânı sunar. Bireylerin kendi kişilik değerlerini inşa etmelerine olanak sağlar ve bireylerin kendi kişilik özellikleri çerçevesinde oluşturdukları öznel ifadelerini diğer kişilerle yani oldukça geniş bir kitle ile paylaşabilmelerine olanak tanır.

Sosyal paylaşım ağları, farklı kişilerin bir araya gelmesiyle kurulan bir ağ zinciri özelliği taşımakta ve ağlar üzerinden oluşturduğu etkileşim ve kimliklerle birçok değer ve değer sistemini birbirine bağlamaktadır. Bir kullanıcı olarak birey, gündelik hayatta pratik haline getirdiği değerleri, sosyal ağlara taşıyabilmektedir. Bu değerler, sosyal ağların platform yapısıyla yeniden şekillenebilmektedir. Özellikle kullanıcının içerik üretiminde inşa ettiği paylaşımlar eşliğinde düşünüldüğünde; "işlevsel, sosyal, duygusal, bilişsel, koşulsal" olarak, bir kategorileşme durumu kazanabilmektedir.

Sosyal paylaşım ağlarının işlevleri sıralandığında; kimlik, sohbet, paylaşım, mevcudiyet, ilişki, şöhret ve grup işlevleri vardır. Sosyal ağların işlevsellikleri, sosyal ağların çoklu yapısına paralel olarak, çok çeşitli etkileşim olanakları ve imkânları sağlamaktadır. Bu çok çeşitli etkileşim içinde kimliklerini oluşturan kullanıcılar, kendi kontrolleri ve istekleri dâhilinde kimliklerine yön verebilmektedir. Kullanıcılar sosyal paylaşım ağlarında üretmiş oldukları içeriklere ve kurdukları etkileşimlere göre, sosyal ağlar ile kendi değer ilişkilerini belirleyebilmektedir.

Son olarak çalışmanın sonucu yerine çalışmanın geliştirilmesi, örnek inceleme ve araştırmalardan oluşan yeni çalışmalar gerçekleştirilmesi ve gelecek çalışmalar için öneriler şu şekilde sıralanabilir;

- Kullanıcıların mevcudiyet işlevi içinde sosyal ağlarda var olmaları, işlevsel değer açısından kullanıcının amaçladığı profilde var olmasını, kişinin bürünmek istediği rol, görünüş, varlık, imaj faaliyetlerini günlük yaşama benzer ya da günlük yaşamdan farklı olarak inceleyen çalışmalar oluşturulabilir ve her iki durum karşılaştırmalı analizlerle ifade edilebilir.

- Sosyal ağların grup işlevi çerçevesinde, kullanıcıların sosyal değerlerle kişisel faaliyetler ya da grup faaliyetlerinde amaçladıkları hedefleri kuşaklararası farklarla (x, y ve z kuşağının kullanım pratiklerindeki farklılıklar) incelemek için çalışmalar oluşturulabilir.

- Sosyal ağların şöhret işlevi çerçevesinde, kullanıcıların duygusal değerlerle benlik durumlarına yönelik hissettikleri, diğer kullanıcılara yönelik faaliyetlerinde gösterdikleri (farklı olma, tanınma, çok sayıda kişi tarafından izlenme, takip edilme ve beğenilme) duygusal reaksiyonlar farklı sosyal ağlar özelinde örneklerle incelenebilir ve karşılaştırmalar yapılabilir. 
- Sosyal ağların kimlik işlevi çerçevesinde, farklı sosyal çevreler ve sosyal kimliklere yönelik, bireysel ve grup kimliklerinin sosyal ağlar temelinde sembolik olarak kimlik inşa etme süreçleri, çoklu sosyal kimlikler gibi örneklerle incelenebilir.

\section{KAYNAKÇA}

ACUN, Ramazan (2011), “Her Dem Yeniden Doğmak: Sosyal Ağlar ve Kimlik”, Milli Folklor, S.89, ss.66-77, http://www.millifolklor.com/pdfviewer.aspx?sayi=89\&sayfa=63 (Erişim Tarihi: 03.03.2020).

AKAR, Erkan (2010), “Sanal Toplulukların Bir Türü Olarak Sosyal Ağ Siteleri: Bir Pazarlama İletişim Kanalı Olarak İşleyişi”, Anadolu Üniversitesi Sosyal Bilimler Dergisi, S.10(1), ss.107-122.

AKYAZI, Erhan ve ATEŞ, Duygu (2012), “Kültürel Kimlik Farkındalı̆̆ Yaratmada Sosyal Ağların Rolü: Manav Türkleri Üzerinde Bir Araştırma”, Sosyal Medya Akademi: İletişim, Pazarlama İletişimi, A Toplumu, Teknoloji (Ed. Tolga Kara ve Ebru Özgen), Beta Basım Yayım Dağıtım, İstanbul, ss.173-194.

ALİKILIÇ, Aşman Özlem (2011), Halkla İlişkiler 2.0 Sosyal Medyada Yeni Paydaşlar, Yeni Teknikler, Efil Yayınevi, Ankara.

ALIKILIÇ, Aşman Özlem ve ONAT, Ferah (2007), "Bir Halkla İlişkiler Aracı Olarak Kurumsal Bloglar", Journal of Yasar University, S.8(2), ss. 899-927.

ARIEL, Yaron ve AVIDAR, Ruth (2015), "Information, Interactivity, and Social Media", Atlantic Journal of Communication, S.23(1), ss.19-30.

AYDOĞAN, Derya (2014), “Romanda Dijitalleşme: E-Kitap”, The Turkish Online Journal of Design, Art and Communication, S.4(4), ss.16-32.

BAKIROĞLU, Cemile Tokgöz (2013), "Sosyalleşme ve Kimlik İnşası Ekseninde Sosyal Paylaşım Ağları", Akademik Bilişim Konferansı Bildiriler Kitabı, 23-25 Ocak 2013 - Antalya, ss.1047-1054.

BOYD, M. Danah ve ELLISON, B. Nicole (2007), "Social Network Sites: Definition, History, and Scholarship”, Journal of Computer-Mediated Communication, S.13(1), ss.210-230.

CALASTRI, Chiara, HESS, Stephane, DALY, Andrew, MANESS, Michael, KOWALD, Matthias ve AXHAUSEN, Kay (2017), "Modelling Contact Mode And Frequency of Interactions With Social Network Members Using The Multiple Discrete-Continuous Extreme Value Model", Transportation Research Part C: Emerging Technologies, S.76, ss.16-34.

CASTELlS, Manuel (2013), Enformasyon Çağı: Ekonomi, Toplum ve Kültür Birinci Cilt: Ăg Toplumunun Yükselişisi (Çev. Ebru K1lıç), İstanbul Bilgi Üniversitesi Yayınları, İstanbul.

ÇAĞLAR, Bayram (2014), "Yerel Kimliğin Sosyal Ağlarda Yeniden İnşası: Hemşeri Derneklerinin Facebook Sayfalarının İncelenmesi”, Yeni Medya Araştırmaları: Kavramlar, Uygulamalar, Tartışmalar (Ed. İdil Sayımer), Literatürk Academia, İstanbul, ss.478-542.

DEĞİRMENCİĞLU, Gürsoy (2016), "Dijitalleşme Çă̆ında Gazeteciliğin Gelişimi ve İnovasyon Haberciliği”, TRT Akademi, S.1(2), ss.590-606.

DİLMEN, Emin N. ve ÖĞÜT, Sertaç (2010), "Sosyalleşmenin Yeni Yüzü: Sosyal Paylaşım Ağları”, Yeni İletişim Ortamları ve Etkileşim Uluslararası Konferansı Bildiriler Kitabı, İstanbul, ss.237-242.

DOĞU, Burak, ÖZÇETIN, Burak, BAYRAKTUTAN, Günseli, BİNARK, Mutlu, ÇOMU, Tuğrul ve AYDEMİR, Aslı Telli (2014), Siyasetin Yeni Hali: Vaka-i Sosyal Medya, Kalkedon Yayınlan, İstanbul.

EKİCI, Murat ve KIYICI, Mübin (2012), “Sosyal Ağların Eğitim Bağlamında Kullanımı”, Uşak Üniversitesi Sosyal Bilimler Dergisi, S.5(2), ss.156-167.

ELLER, Robert, ALFORD, Philip, KALLMÜNZER, Andreas ve PETERS, Mike (2020), "Antecedents, Consequences, and Challenges of Small and Medium-Sized", Journal of Business Research, S.(112), ss.119-127.

GEBAUER, Heiko, FLEISCH, Elgar, LAMPRECHT, Claudio ve WORTMANN, Felix (2020), "Growth Paths for Overcoming The Digitalization Paradox", Business Horizons, S.63(3), ss.1-11. 
GENÇ, Hakan (2010), “ínternetteki Etkileşim Merkezi Sosyal Ağlar ve E-İş 2.0 Uygulamaları”, Akademik Bilişim, S.10(12), ss.481-487.

GILPIN, R. Dawn (2010), "Working the Twittersphere: Microblogging as Professional Identity Construction", A Networked Self Identity, Community and Culture on Social Network Sites (Ed. Zizi Papacharissi), Routledge Publisher, Londra, ss.240-258.

GOFFMAN, Erving (2009), Günlük Yaşamda Benliğin Sunumu (Çev. Barış Çezar), Metis Yayınları, Ankara.

GÜÇDEMİR, Yeşim (2015), Sanal Ortamda İletişim Bir Halkla İlişsiler Perspektifi, Derin Yayınları, İstanbul.

GÜNEŞ UÇA, E. Pınar (2016), “Toplumsal Değişim, Teknoloji ve Eğitim İlişkisinde Sosyal Ağların Yeri”, Açıköğretim Uygulamaları ve Araştırmaları Dergisi, S.2(2), ss.191-206.

GVILI, Yanil, KOL, Ofrit ve LEVY, Shalom (2019), "The Value(S) of Information on Social Network Sites: The Role of User Personality Traits", European Review of Applied Psychology, S.2(70), ss.1-12.

HALSTEAD, J. Mark ve TAYLOR, Monica (2000), "Learning Teaching and About Values: A Review of Resent Research”, Cambridge Journal of Education, S.2(30), ss.169-202.

HU, Yuheng, MANIKONDA, Lydia ve KAMPHAMPATI, Subbaro (2014), "What We Instagram: A Firs Analysis of Instagram Photo Contet And User Types", Icwsm, http://149.169.27.83/instagram-icwsm.pdf (Erişim Tarihi: 11.08.2020).

HÜLÜR, Banu (2017), “Erving Goffman: Günlük Yaşamda Benliğin Sunumu”, Abant Kültürel Araştırmalar Dergisi, S.4(2), ss.332-339.

KARADUMAN, Hıdır, ÇENGELCİ KÖSE, Tuba ve ERYILMAZ, Önder (2017), "Sosyal Bilgiler Öğretmen Adaylarına Göre Sosyal Medyada Değerler”, Turkish Online Journal of Qualitative Inquiry, S.8(2), ss.250-271.

KAYMAS, Serhat (2016), “Yeni Bağlamlarında Devam Eden Sorunlar: Dijital Kapitalizm ve Kullanıcı Emeğini Yeniden Düşünmek Üzerine”, Intermedia International E-journal, S.3(5), ss.320-343.

KIETZMANN, H. Jan, HERMKENS, Kristopher, McCARTHY, P. Ian ve SILVESTRE, S. Bruno (2011), "Social Media? Get Serious! Understanding The Functional Building Block of Social Media", Business Horizons, S.54, ss.241-251.

KIRIK, Murat Ali (2012), “Arap Baharı Bağlamı'nda Sosyal Medya-Birey Etkileşimi ve Toplumsal Dönüşüm”, 21. Yüzyılda Eğitim ve Toplum Dergisi, S.1(3), ss.87-98.

KÖSEOĞLU, Özgür (2012), "Sosyal Ă̆ Sitesi Kullanıcllarının Motivasyonları: Facebook Üzerine Bir Araştırma”, Selçuk Üniversitesi İletişim Fakültesi Dergisi, S.7(2), ss.58-81.

MANOVICH, Lev (2017), Instagram and Contemporary Image, New York, http://manovich.net/content/04projects/153-instagram-and-contemporary-image/instagram_book_manovich_2017.pdf (Erişim Tarihi: 11.08.2020).

MEMiș, Levent (2015), "Yerel E-Katılımın Yeni Aracı Olarak Sosyal Ağlar: Facebook ve Twitter Örnekleri", Çankırı Karatekin Üniversitesi İktisadi ve İdari Bilimler Fakültesi Dergisi, S.5(1), ss.209-242.

OECD (2017), Key Issues for Digital Transformation in the G20, OECD Publisher, Berlin.

O'REILLY, Tim (2010), "What Is Web 2.0? Design Patterns and Business Models For The Next Generation of Software”, Online Communication and Collaboration A Reader (Ed. Helen Donelan, Karen Kear ve Magnus Ramage), Routledge and Francis Group Publisher, New York and London, ss.225-234.

ÖZDEMIR, Zafer (2015), "Sosyal Medyada Kimlik İnşasında Yeni Akım: Özçekim Kullanımı”, Maltepe Üniversitesi İletişim Fakültesi Dergisi, S.2(1), ss.112-131.

ÖZDEMIR, Zafer ve ÇETINKAYA, Aysel (2014), "Müşteri Etkisi Yaratma Açısından Sosyal Medya: Türkiye'deki Hazır Giyim Lovemark'ları Üzerine Bir Inceleme”, Uluslararası İletişim Bilimi ve Medya Kongresi Bildiriler Kitabı, Kocaeli, ss.1-21.

ÖZKAN, Gülden Şap (2014), “A ğ Tabanlı Sahnede Benliğin Sunumu: İdealize Edilmiş Duygular”, Yeni Medya Araştırmaları: Kavramlar, Uygulamalar, Tartışmalar (Ed. İdil Sayımer), Literatürk Academia, İstanbul, ss.243-282. 
CARLIK, Mehmet ve ÖZTÜRK TERZİ, Aslı - Sosyal Ağlar Üzerinden Değerler, Etkileşimler ve Kimlikleri Yönetmek

ÖZMEN, Fatma, AKÜZÜM, Cem, SÜNKÜR, Meltem ve BAYSAL, Nigah (2012), "Sosyal A $\breve{g}$ Sitelerinin Ĕgitsel Ortamlardaki İ̧slevselliği”, NWSA- Education Sciences, S.7(2), ss.496-506.

PERSHINA, Raissa, SOPPE, Birth ve THUNE, Mari Taran (2019), "Bridging Analog and Digital Expertise: Cross-Domain Collaboration and Boundary-Spanning Tools in The Creation of Digital Innovation", Research Policy, S.9(48), ss.1-13.

SAYIMER, İdil (2008), Sanal Ortamda Halkla İlişsiler, Beta Basım Yayım ve Dağıtım, İstanbul.

SHIPPS, Belinda ve PHILIPS, Brandis (2013), "Social Networks, Interactivity and Satisfaction: Assessing Socio-Technical Behavioral Factors as an Extension to Technology Acceptance”, Journal of Theoretical and Applied Electronic Commerce Research, S.8(1), ss.35-52.

SLEVIN, James (2007), Wiley Online Library, https://onlinelibrary.wiley.com/doi/abs/10.1002/9781405165518.wbeosi061 (Erişim Tarihi: 15.06.2020).

ŞAHOĞLU, Tokgöz Cemile (2018), "Kullanımlar ve Doyumlar Yaklaşımı Çerçevesinde Konum Paylaşım Motivasyonlart: Foursquare ve Swarm Üzerine Nitel Bir Araştırma”, Marmara Üniversitesi İletişim Fakülttesi Dergisi, S.(29), ss.258-278.

TOFFLER, Alvin (1980), Üçüncü Dalga (Çev. Selim Yeniçeri), Koridor Yayıncılık, İstanbul.

TONTA, Yaşar (2009), “Dijital Yerliler, Sosyal Ağlar ve Kütüphanelerin Geleceği”, Türk Kütüphaneciliği, S.23(4), ss.742-768.

TOPRAK, Ali, YILDIRIM, Ayşenur, AYGÜL, Eser, BİNARK, Mutlu, BÖREKÇİ, Senem ve ÇOMU, Tuğrul (2014), Toplum Paylaşım Ağı Facebook: "Görülüyorum Öyleyse Varım", Kalkedon Yayınları, İstanbul.

TUNÇEL, Ahu (2014), “Gençlerin Sosyal Medya Kullanımı ve Demokratik Siyaset”, Yeni Medya Pratikler Olanaklar (Ed. Emel Baştürk Akca), Umuttepe Yayınları, Kocaeli, ss.59-78.

TURAN, Alper Erdem (2014), "Yeni Medya Ortamları İle Dönüşen İzleyicinin Elektronik Sözlük ve Talk Show Ara Kesitinde İzlenmesi”, Yeni Medya Araştırmaları: Kavramlar, Uygulamalar, Tartışmalar (Ed. İdil Sayımer), Literatürk Academia, İstanbul, ss.99-148.

TÜRKER, Masum (2018), "Dijitalleşme Sürecinde Küresel Muhasebe Mesleğinin Yeniden Şekillenmesine Bir Bakış”, Muhasebe Bilim Dünyası Dergisi, S.20(1), ss.202-235.

ULUK, Murat (2018), Hakikat Sonrası Çağda Yeni Medya ve Yalan Haber, Dorlion Yayınevi, Ankara.

USLUEL, Yasemin Koçak, DEMİR, Ömer ve ÇINAR, Murat (2014), "Sosyal Ağların Kullanım Amaçları Ölçeği”, Eğitim Teknolojileri Araştırma Dergisi, S.5(2), ss. 1-18.

VERHOEF, Peter C., BROEKHUIZEN, Thijs, BART, Yakov, BHATTACHARYA, Abhi, DONG, John Qi, FABIAN, Nicolai ve HAENLEIN, Michael (2019), "Digital Transformation: A Multidisciplinary Reflection and Research Agenda", Journal of Business Research, S.122, ss.1-13.

VURAL, Beril Zerrin ve BAT, Mikail (2010), "Yeni Bir Iletişim Ortamı Olarak Sosyal Medya: Ege Üniversitesi Iletişim Fakültesine Yönelik Bir Araştırma”, Journal of Yasar University, S.5(20), ss.3348-3382.

YEĞEN, Ceren (2013), "Demokratik ve Yeni Bir Kamusal Alan Olarak Sosyal Medya", Muş Alparslan Üniversitesi Sosyal Bilimler Dergisi, S.1(2), ss.119-135.

YILDIZ, Muammer (2017), "Postmodern İletişim Süreçleri ve Sanal Şöhret”, Middle Black Sea Journal of Communication Studies, S.2(1), ss.16-23.

YILDIRIM, Şeyma, ÖZDEMIR, Murat ve ALPARSLAN, Ece (2018), "Kullanımlar ve Doyumlar Kuramı Çerçevesinde Bir Sosyal Ağı Paylaşımı İncelemesi: Facebook Örneği”, Intermedia International EJournal, S.8(5), ss. 42-65.

YILDIRIM, Arif (2012), "Sosyal Ağlar ve Kişisel Gizlilik Çatışması”, Sosyal Medya Akademi: İletişim,

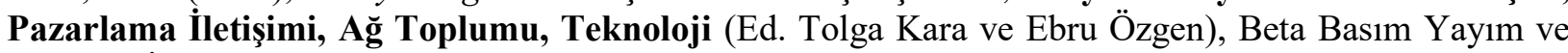
Dağıtım, İstanbul, ss.243-267.

ZHAO, Shanyang, GRASMUCK, Sherri ve MARTIN, Jason (2008), "Identy construction on Facebook: Digital empowerment in anchored relationships", Computer in Human Behavior, S.24, ss.1816-1836. 